In cooperation with the City of San Antonio

\title{
Geologic Framework and Hydrogeologic Characteristics in the Southern Part of the Rancho Diana Natural Area, Northern Bexar County, Texas, 2008-10
}

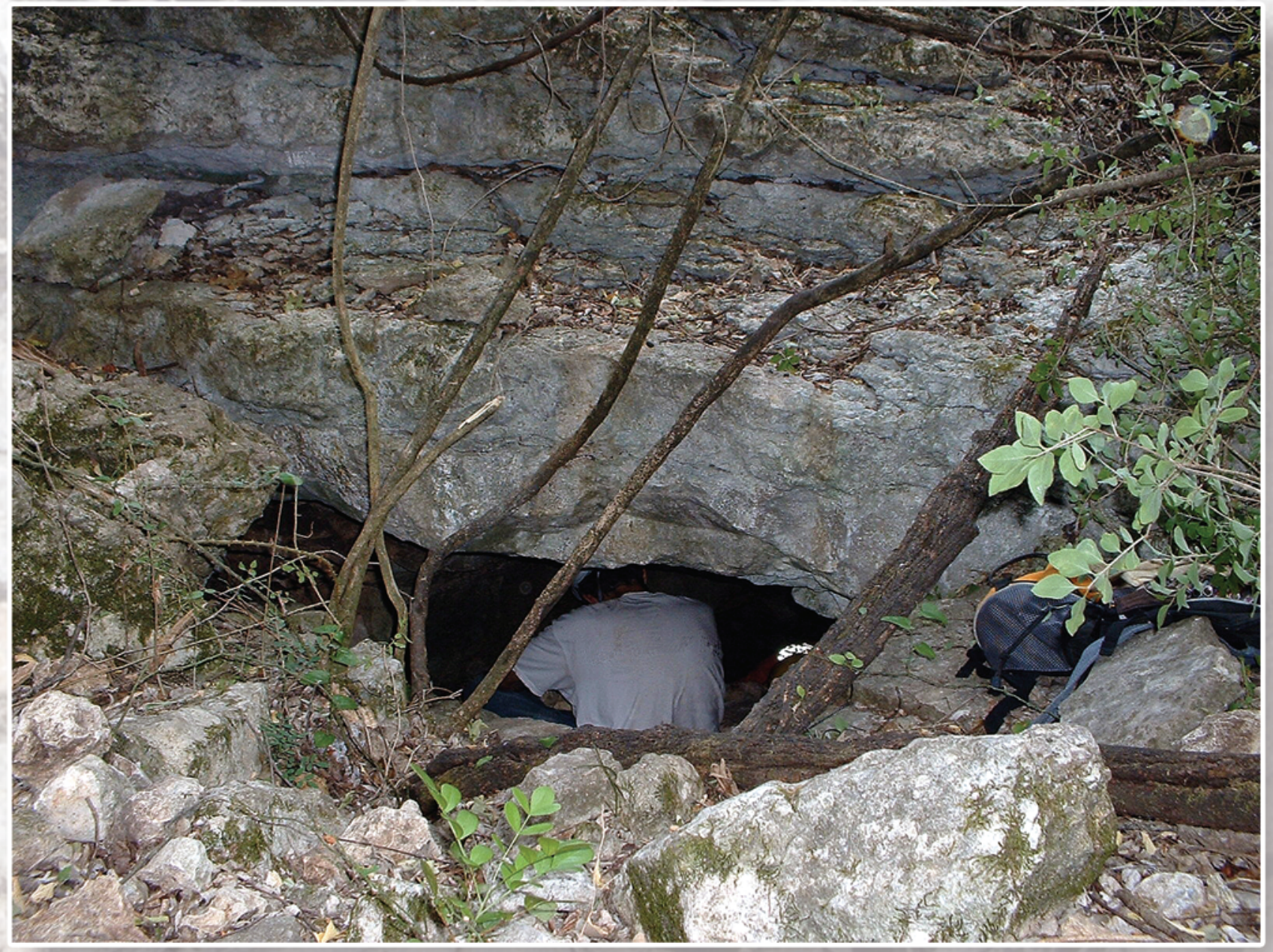

Scientific Investigations Report 2011-5069 
Cover. Cave that developed in the hydrogeologic cavernous subdivision near the contact of the Edwards and Trinity aquifers in the southern part of the Ranch Diana Natural Area, nothern Bexar County, Texas. Photograph by U.S. Geological Survey personnel. 


\section{Geologic Framework and Hydrogeologic Characteristics in the Southern Part of the Rancho Diana Natural Area, Northern Bexar County, Texas, 2008-10}

By Allan K. Clark and Robert R. Morris

In cooperation with the City of San Antonio

Scientific Investigations Report 2011-5069 


\section{U.S. Department of the Interior \\ KEN SALAZAR, Secretary \\ U.S. Geological Survey \\ Marcia K. McNutt, Director}

\section{U.S. Geological Survey, Reston, Virginia: 2011}

For more information on the USGS — the Federal source for science about the Earth, its natural and living resources, natural hazards, and the environment, visit http://www.usgs.gov or call 1-888-ASK-USGS.

For an overview of USGS information products, including maps, imagery, and publications, visit http://www.usgs.gov/pubprod

Any use of trade, product, or firm names is for descriptive purposes only and does not imply endorsement by the U.S. Government.

Although this report is in the public domain, permission must be secured from the individual copyright owners to reproduce any copyrighted materials contained within this report.

Suggested citation:

Clark, A.K., and Morris, R.R., 2011, Geologic framework and hydrogeologic characteristics in the southern part of the Rancho Diana Natural Area, northern Bexar County, Texas, 2008-10: U.S. Geological Survey Scientific Investigations Report 2011-5069, 19 p. 


\section{Acknowledgments}

The authors would like to thank Eric Lautzenheiser and Don Pylant of the San Antonio Parks and

Recreation Department, San Antonio, Texas, for their helpful comments and insights throughout the project. In addition, the authors thank U.S. Geological Survey volunteers for science, Amy C.E. Morris and Mark Childre, who assisted with the geologic reconnaissance. 


\section{Contents}

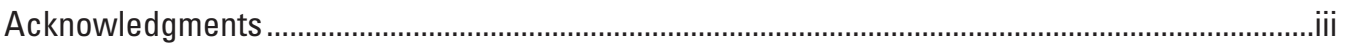

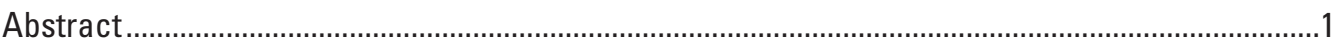

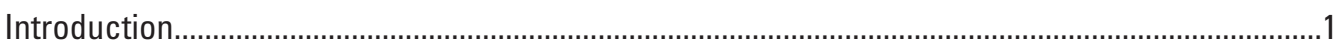

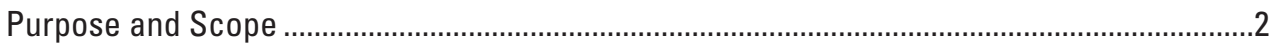

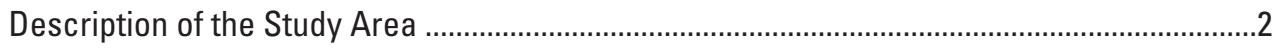

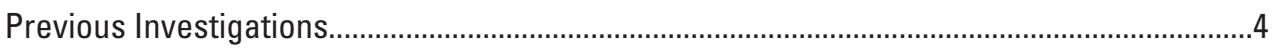

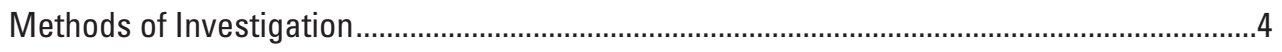

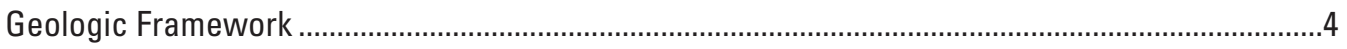

Stratigraphy of Trinity Group (Glen Rose Limestone)..............................................................5

Contact Between the Trinity and Edwards Groups ………....................................................

Stratigraphy of the Edwards Group .................................................................................

Structural Features

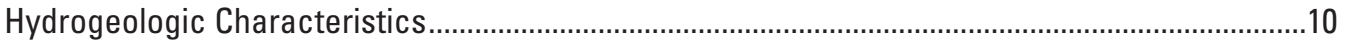

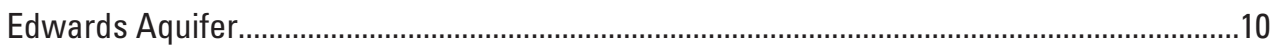

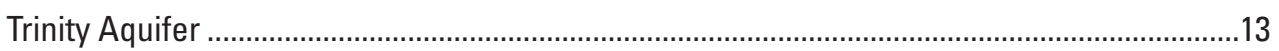

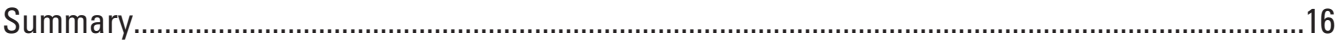

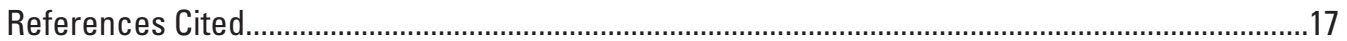

\section{Figures}

1. Map showing location of the study area...

2. Map showing geologic framework and hydrogeologic characteristics of the study area, along with locations of faults, caves, and karst features other than caves, in the southern part of the Rancho Diana Natural Area, northern Bexar County, Texas

3. Photograph of a typical chert nodule found in the southern part of the Rancho Diana Natural Area, northern Bexar County, Texas...

4. Photograph showing an example of the contact between the Kirschberg evaporite member in the foreground and grainstone member of the southern part of the Rancho Diana Natural Area, northern Bexar County, Texas

5. Photographs showing examples of boxwork moldic porosity from evaporite beds.

6. Photograph showing examples of fabric-selective moldic porosity in a limestone nodule containing chert observed in the southern part of the Rancho Diana Natural Area, northern Bexar County, Texas

7. Photograph showing examples of fabric-selective fenestral porosity in hydrogeologic subdivision VI of the Edwards aquifer observed in the southern part of the Rancho Diana Natural Area, northern Bexar County, Texas 
8 Photograph showing examples of fabric-selective moldic porosity (caprinic mold and channel porosity at the top of hydrogeologic subdivision VII (dolomitic member) observed in the southern part of the Rancho Diana Natural Area, northern Bexar County, Texas

9. Simplified schematic representation of infiltration, discharge, and runoff processes in the southern part of the Rancho Diana Natural Area,

northern Bexar County, Texas

10. Photograph showing an example of a cave that developed in the hydrogeologic cavernous subdivision near the contact of the Edwards and upper Trinity aquifers in the southern part of the Rancho Diana Natural Area, northern Bexar County, Texas

11. Photograph showing an example of a cave that developed along a bedding plane in the cavernous subdivision of the upper Trinity aquifer in the southern part of the Rancho Diana Natural Area, northern Bexar County, Texas.

\section{Table}

1. Summary of the geologic framework and hydrogeologic characteristics of the Edwards and upper Trinity aquifers outcropping in the southern part of the Rancho Diana Natural Area, northern Bexar County, Texas .

\section{Conversion Factors and Datum}

Inch/Pound to SI

\begin{tabular}{|c|c|c|}
\hline Multiply & By & To obtain \\
\hline \multicolumn{3}{|c|}{ Length } \\
\hline inch (in.) & 25.4 & millimeter $(\mathrm{cm})$ \\
\hline inch (in.) & 2.54 & centimeter $(\mathrm{cm})$ \\
\hline foot $(\mathrm{ft})$ & 0.3048 & meter (m) \\
\hline mile (mi) & 1.609 & kilometer $(\mathrm{km})$ \\
\hline \multicolumn{3}{|c|}{ Area } \\
\hline acre & 0.4047 & hectare (ha) \\
\hline \multicolumn{3}{|c|}{ Slope } \\
\hline foot per mile (ft/mi) & 0.1894 & meter per kilometer $(\mathrm{m} / \mathrm{km})$ \\
\hline
\end{tabular}

Vertical coordinate information is referenced to National Geodetic Vertical Datum of 1929 (NGVD 1929).

Horizontal coordinate information is referenced to the North American Datum of 1983 (NAD 83). 



\title{
Geologic Framework and Hydrogeologic Characteristics in the Southern Part of the Rancho Diana Natural Area, Northern Bexar County, Texas, 2008-10
}

\author{
By Allan K. Clark and Robert R. Morris
}

\section{Abstract}

The area designated by the city of San Antonio as the Rancho Diana Natural Area is in northern Bexar County, near San Antonio, Texas. During 2008-10, the U.S. Geological Survey, in cooperation with the city of San Antonio, documented the geologic framework and mapped the hydrogeologic characteristics for the southern part of the Rancho Diana Natural Area. The geologic framework of the study area and its hydrogeologic characteristics were documented using field observations and information from previously published reports. Many of the geologic and hydrogeologic features were found by making field observations through the dense vegetation along gridlines spaced approximately 25 feet apart and documenting the features as they were located. Surface geologic features were identified and hydrogeologic features such as caves, sinkholes, and areas of solutionally enlarged porosity were located using hand-held Global Positioning System units. The location data were used to create a map of the hydrogeologic subdivisions and the location of karst features. The outcrops of the Edwards and Trinity aquifer recharge zones were mapped by using hydrogeologic subdivisions modified from previous reports. All rocks exposed within the study area are of sedimentary origin and Lower Cretaceous in age. The valley floor is formed in the cavernous member of the upper Glen Rose Limestone of the Trinity Group. The hills are composed of the basal nodular member, dolomitic member, Kirschberg evaporite member, and grainstone member of the Kainer Formation of the Edwards Group. Field observations made during this study of the exposed formations and members indicate that the formations and members typically are composed of mudstones, wackestones, packstones, grainstones, and argillaceous limestones, along with marls. The upper Glen Rose Limestone is approximately 410 to 450 feet thick but only the upper 70 feet is exposed in the study area. The Kainer Formation is approximately 255 feet thick in the study area and is composed of, in ascending order, the basal nodular member, dolomitic member, Kirschberg evaporite member, and grainstone member. The Edwards and Trinity aquifers contain a combination of fabric-selective and not-fabric-selective porosities. Porosity types observed in the study area that can increase the effective porosity and increase permeability include solutionally enlarged caves, sinkholes, fractures, bedding planes, channels, molds and vugs. Caves found during hydrogeologic mapping might have been spring discharge points, but sufficient downcutting over geologic time in the rocks has occurred so that springs discharge at lower elevations near the creek channel. The mapped caves, sinkholes, and other areas of solutionally enlarged porosity might facilitate recharge during large storm events when runoff occurs on the hillsides; additional areally distributed recharge in the study area occurs as a result of infiltration.

\section{Introduction}

The area designated by the city of San Antonio as the Rancho Diana Natural Area (fig. 1) is in northern Bexar County near San Antonio, Tex. The study area consists of outcrops of the Edwards and Trinity group, which form the recharge zones for the Edwards and Trinity aquifers, respectively. The outcrops are intensely faulted and fractured soluble limestones and dolomites form the Edwards and Trinity aquifers (Hanson and Small, 1995; Stein and Ozuna, 1996).

Dissolution of the carbonate rocks composing the Edwards and Trinity aquifers results in distinctive landforms noted for abundant springs and karst features (caves, sinkholes, and other visible areas of solutionally enlarged porosity). The same characteristics that result in abundant springs also result in aquifers that are susceptible to contamination because stormwater runoff is quickly transferred to the subsurface (Ryan and Meiman, 1996). Caves, sinkholes, and other karst features can have appreciable effect on the hydrogeologic characteristics of an area because they can act as points of focused recharge (Hanson and Small, 1995; U.S. Geological Survey, 2011a).

As the city of San Antonio rapidly grew toward the north and northwest in the 1990s, San Antonio city managers became concerned that environmentally sensitive areas overlying the Edwards and Trinity aquifer recharge zones would 
become largely urbanized, increasing the potential for contamination of groundwater (Clark, 2000). Since 2000, the city of San Antonio has been acquiring properties for the purpose of limiting development where contamination of the Edwards aquifer was deemed likely if no conservation plans were implemented (city of San Antonio, 2010a). The 1,074-acre Rancho Diana Natural Area was purchased by the city of San Antonio in 2001 and 2002 with the plan of eventually developing it into a park with hiking trails and a visitor center (city of San Antonio, 2010b). Rancho Diana Natural Area is currently (2011) undeveloped land with the exception of a few historic roads and buildings. Detailed hydrogeologic characteristics of the Rancho Diana Natural Area are needed by water-resource managers to identify areas in which effects from urbanization might affect groundwater resources.

Stein and Ozuna (1996) described the regional geologic framework and hydrologic characteristics of the Edwards aquifer recharge zone in Bexar County and mapped the outcrop of the Edwards aquifer recharge zone, using hydrogeologic subdivisions modified from Maclay and Small (1976). Stein and Ozuna (1996) described the Edwards aquifer as one of the most permeable and productive aquifers in the world, the most prolific groundwater source in Bexar County, and the primary source of water for most of San Antonio; they also noted it was susceptible to contamination in areas where it outcrops. Clark and others (2009) described the geologic framework and hydrostratigraphy of the Trinity aquifer in northern Bexar County on the basis of the modified hydrogeologic subdivisions from Clark (2003). Barker and Ardis (1996) noted that the Trinity aquifer is a vital water supply to much of northern Bexar County and other areas mostly north and northwest of San Antonio. In addition to supplying water to numerous springs that support several endangered species, the Edwards and Trinity aquifers supply much of the water used for agricultural, municipal, commercial, and industrial purposes in south-central Texas. Most of the recharge to the Edwards and Trinity aquifers is a result of direct infiltration on their respective recharge zones, much of which is concentrated in streambeds (Ashworth, 1983; Stein and Ozuna, 1996). Streambeds in karstic terrains often have features facilitating focused recharge such as caves, sinkholes, and other areas of solutionally enlarged porosity (Phillips and others, 2004; Field, 2006).

Compared to the information available in previous reports, more detailed hydrogeologic characteristics of the Rancho Diana Natural Area are needed by water-resource managers to identify areas in which urbanization of the recharge zones of the Edwards and Trinity aquifers might affect groundwater resources. Accordingly, the U.S. Geological Survey, in cooperation with the city of San Antonio, documented the geologic framework and mapped the hydrogeologic characteristics for the southern part of the Rancho Diana Natural Area in northern Bexar County, Tex., during 2008-10 (fig. 1).

\section{Purpose and Scope}

This report characterizes the geologic framework and provides a hydrogeologic map of the southern part of the Rancho Diana Natural Area. The geologic framework was investigated because it controls the development of hydrogeologic features. Detailed surface expressions of the geology and hydrogeologic characteristics were mapped. Hydrogeologic features such as caves, sinkholes, and other visible areas of solutionally enlarged porosity were mapped to provide information on possible points of focused recharge. Although many features were identified as points of focused recharge, some features were likely not documented because they were obscured by dense vegetation.

\section{Description of the Study Area}

The study area is dominated by rocky hills. Consistent with similar terrain in Northern Bexar County, soils on rocky hills are thin and alkaline; in the lowlands separating the hills, the soils range from shallow to deep and loamy (Handbook of Texas Online, 2010). The rocky area is densely vegetated with tall and medium-height grasses, live oak (Quercus virginiana), Ashe juniper (locally called mountain cedar, [Jumiperus ashei]), and mesquite (various varieties; Honey Mesquite [Prosopis glandulosa Torr.] is one of the dominant species in Texas) (Handbook of Texas Online, 2010; Saleh and others, 2009). The surface geology consists of the outcrops of the formations composing the Edwards and Trinity Groups. Elevations range from 1,075 to $1,361 \mathrm{ft}$ above National Geodetic Vertical Datum of 1929 at the southeastern and western boundaries, respectively. The southern part of the Rancho Diana Natural Area is drained by two unnamed ephemeral streams, one of which has three tributaries and drains through a valley floor (fig.1). The lower areas of the drainages and the tops of the elevated areas are characterized by nearly level to gentle slopes (less than 4 percent); slopes from 15 to 25 percent are found throughout the study area. The nearest National Weather Service meteorological station is 13 miles southeast of the study area at the San Antonio International Airport (fig. 1); average annual rainfall at the station during 1971-2000 was 32.92 inches. Although most rainfall occurs in the spring and fall, heavy rain resulting in flash flooding and large amounts of recharge can occur during any season (National Weather Service, 2010). 


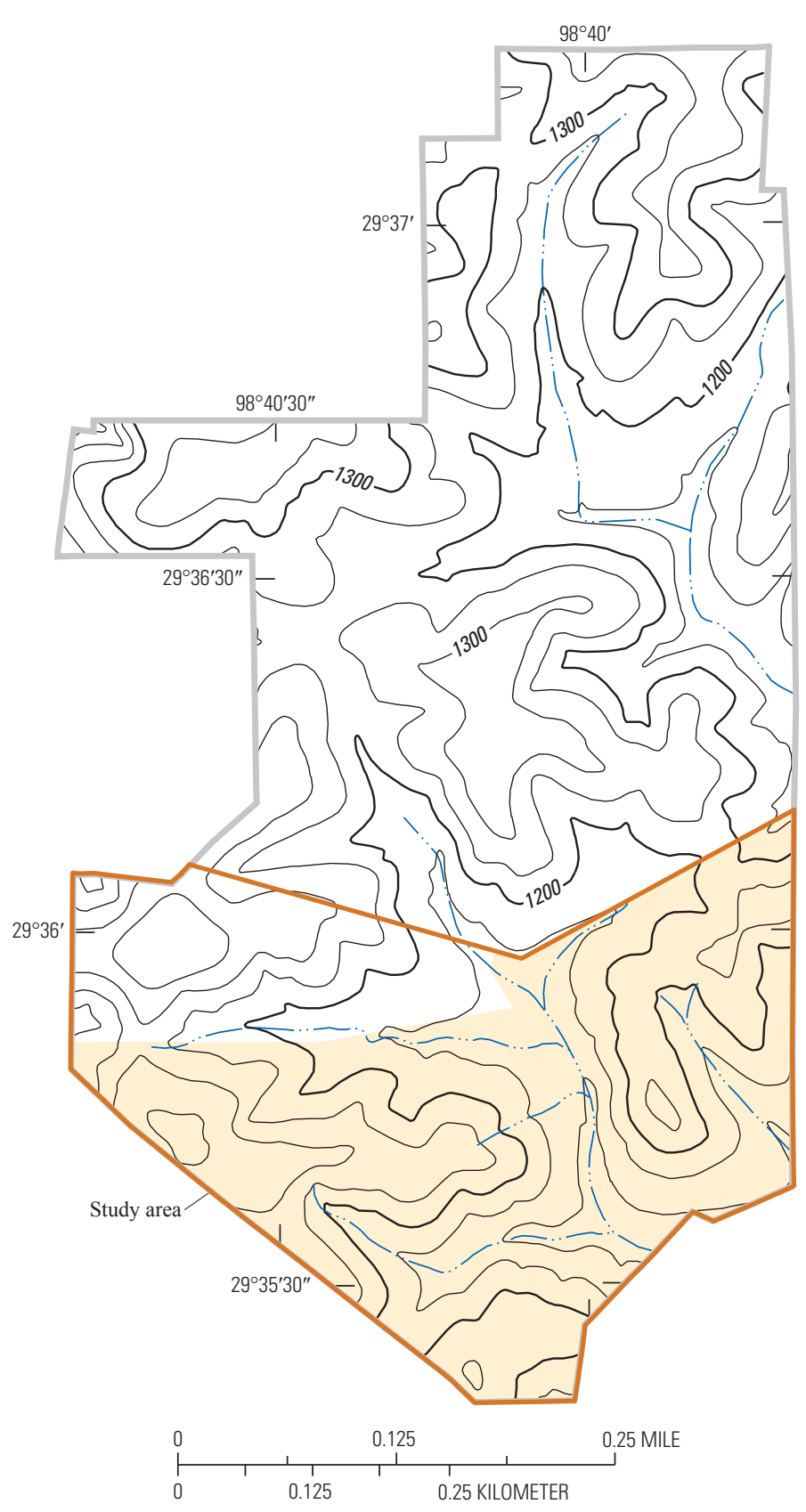

Figure 1. Location of the study area.
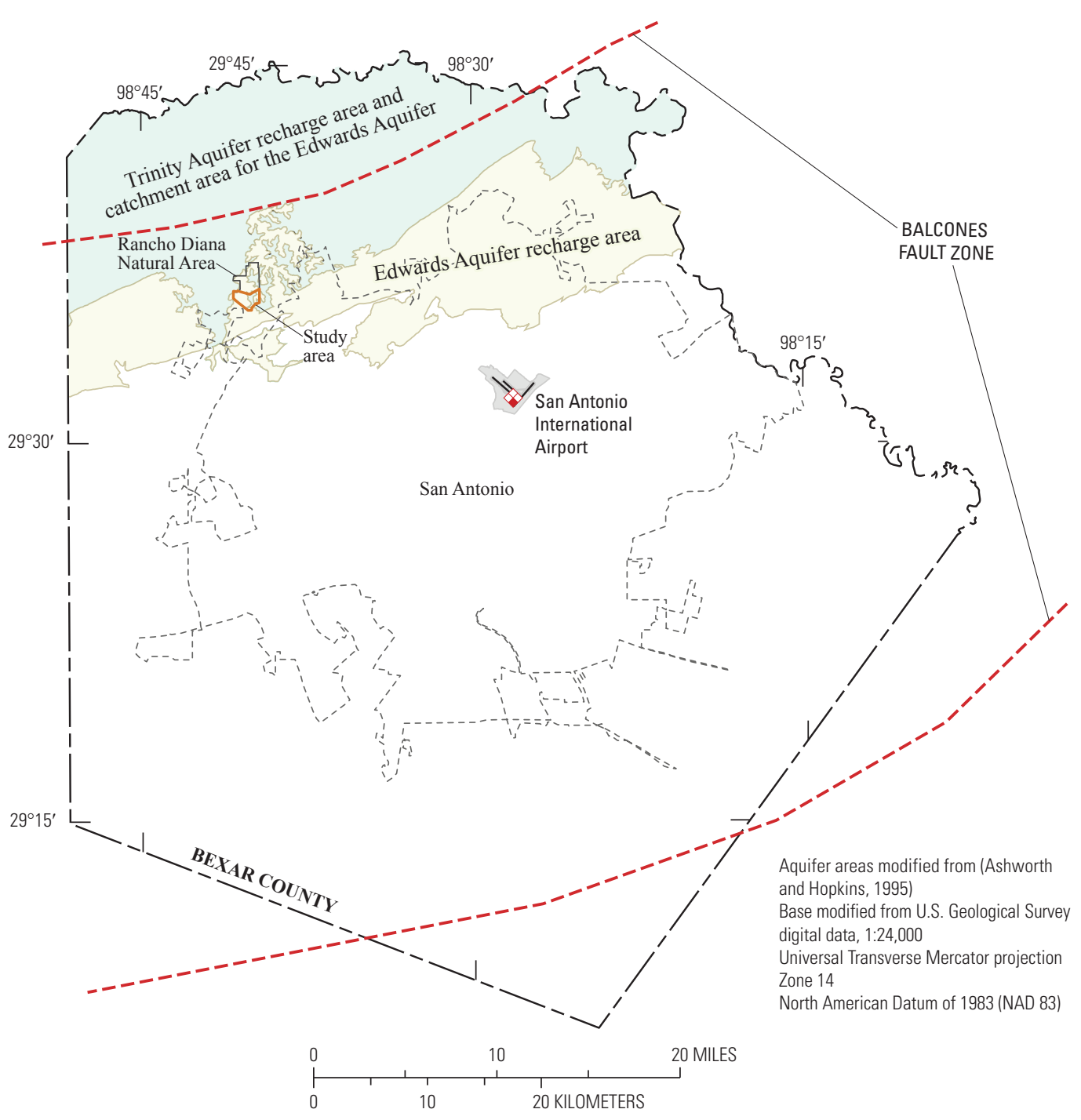

EXPLANATION

Karst features mapping area

tudy area boundary (geologic framework and

hydrogeologic characteristics mapping area)

\section{Rancho Diana Natural Area boundary}

-1200- Topographic contour-Contour interval 50 feet. Datum is National Geodetic Vertical Datum of 1929

National Weather Service meteorological station 417945 


\section{Previous Investigations}

The Glen Rose Limestone, which is the upper formation of the Trinity Group, was first subdivided into upper and lower members by Whitney (1952). Lozo and Smith (1964) established the nomenclature of the Trinity Group. Barker and others (1994) noted rocks of the Trinity Group comprise the Trinity aquifer, and synthesized and summarized previous studies to describe the stratigraphy and hydrogeologic units of the Edwards and Trinity aquifers. Ashworth (1983) subdivided the Trinity aquifer into the upper Trinity aquifer, middle Trinity aquifer, and lower Trinity aquifer. Clark $(2003,2005)$ subdivided the upper Trinity aquifer into five mappable intervals. Clark and others (2009) extended the earlier hydrogeologic subdivisions (Clark 2003, 2005) through northern Bexar County and named the five hydrogeologic subdivisions (top to bottom) as the cavernous, Camp Bullis, upper evaporite, fossiliferous, and lower evaporite hydrostratigraphic members.

Maclay and Small (1986) summarized the seminal studies on regional stratigraphy and descriptions of stratigraphic nomenclature of the Edwards Group and equivalent rocks in South Texas done by Lozo and Smith (1964), Fisher and Rodda (1969), and Rose (1972). Maclay and Small (1976) described eight hydrogeologic subdivisions of the Edwards aquifer in the subsurface on the basis of Rose's (1972) lithostratigraphic work and included the Georgetown Formation (Freeman, 1964) as the upper subdivision of the Edwards aquifer. Stein and Ozuna (1996) extended the hydrogeologic subdivisions of Maclay and Small (1976) into the surface outcrops.

Barker and Ardis (1996) provided a regional synthesis of the hydrogeologic framework of the Edwards-Trinity aquifer systems for a large area of west-central Texas, which included northern Bexar County and the study area. Small (1985) and Shah and others (2008) provided information on the contacts between the formations of Edwards and Trinity Groups derived from surface geophysical studies.

\section{Methods of Investigation}

Previous geologic maps and reports (Stein and Ozuna, 1996; Clark and others, 2009) covering parts of northern Bexar County were used as the starting point for documenting the geologic framework and hydrogeologic characteristics of the study area. Previous interpretations of the origin and age of the formations present in northern Bexar County were applied to the study area. Information from existing hydrogeologic maps and previous characterizations of the hydrogeologic subdivisions in the study area was compiled. The outcrop of the Edwards aquifer recharge zone was mapped by using the hydrogeologic subdivisions modified from Maclay and Small (1976). The outcrop of the upper Trinity aquifer was mapped by using hydrogeologic subdivisions (Clark, 2003, 2005) as modified by Clark and others (2009).
Changes in patterns of vegetation observed in aerial photographs sometimes provided clues to the possible locations of karst features and faults. In some cases, the detailed surface expressions of the geology are partly obscured in aerial photographs by vegetation. Geologic and hydrogeologic features were found by making field observations through the dense vegetation along gridlines spaced approximately $25 \mathrm{ft}$ apart. The latitude, longitude, and elevation of contacts, faults, and karst features were recorded by using hand-held Global Positioning System (GPS) units.

Where possible, thicknesses of exposed formations and members and locations of geologic contacts were determined during field surveys. For example, where the outcrops are incised by a stream or offset by faulting, formation thicknesses were measured and locations of geologic contacts were documented. The classification systems of Dunham (1962) and Choquette and Pray (1970) were used to describe the exposed carbonate rocks in the study area. Dunham's (1962) carbonate-rock classifications - determined on the basis of the arrangement and ratio of fine to coarse sediment, from mudstone through grainstone - were used to describe the facies of the exposed hydrogeologic members. The porosity classifications of Choquette and Pray (1970) were then used to characterize the porosity of those facies types as either fabric selective or not-fabric selective. Fabric-selective porosity is secondary porosity that preferentially developed along specific sedimentary structures, strata, or mineralogy. Not-fabricselective porosity is secondary porosity that developed without the influence of sedimentary structures and is not associated with the original sedimentary or diagenetic process but rather is caused by other geologic processes such as fracturing and faulting (Choquette and Pray, 1970).

Detailed, on-the-ground field mapping was done for the southern part of the Rancho Diana Natural Area, with the exception of 109 acres in the northwestern corner of the study area. The geology of those 109 acres was documented by spot checking the geologic contacts on the ground and comparing that information to previously published reports describing the hydrogeology of northern Bexar County (Stein and Ozuna, 1996; Clark and others, 2009). On-the-ground field mapping information was combined with geologic information from previously published reports relevant to the 109-acre area to produce a complete map depicting the hydrogeologic subdivisions of the Edwards and Trinity aquifers for the study area. The locations of faults and karst features documented during on-the-ground field mapping are also shown on the same map.

\section{Geologic Framework}

The geologic framework of the study area is best understood in the context of the surface expressions of the geology. Previous investigations have shown that rocks observed in the study area are of sedimentary origin and Lower Cretaceous in age (Rose, 1972). A valley floor formed along the unnamed 
ephemeral stream drained by three tributaries; the valley floor is the cavernous member (fig. 2) of the Glen Rose Limestone (Lozo and Smith, 1964) of the Trinity Group (Barker and others, 1994). The hills are composed of the basal nodular member, dolomitic member, Kirschberg evaporite member, and grainstone member of the Kainer Formation of the Edwards Group (Rose, 1972) (table 1). Field observations made during this study of the exposed formations and members also indicate the formations and members typically are composed of mudstones, wackestones, packstones, grainstones, and argillaceous limestones, along with marls. The overlying Person Formation of the Edwards Group has been removed by erosion from the study area. The surface expressions of the formations in the Trinity and Edwards Groups are shown in figure 2. The only part of the Trinity Group exposed in outcrop in the study area is the cavernous member.

\section{Stratigraphy of Trinity Group (Glen Rose Limestone)}

The Glen Rose Limestone (Hill, 1891; Lozo and Smith, 1964) of the Trinity Group (Barker and others, 1994) in southcentral Texas is partly clayey and sandy; it was deposited in shallow marine environments (neritic [sublittoral] facies) (Sellards and others, 1933). The Glen Rose Limestone is approximately 720-770 ft thick in the San Antonio area (Ashworth, 1983) and is separated into upper and lower members (Whitney, 1952). The upper Glen Rose Limestone is approximately $410-450 \mathrm{ft}$ thick in the study area. Clark and others (2009) extended the subdivisions identified by Clark (2003) of the upper Glen Rose Limestone throughout northern Bexar County and described them for geologic and hydrogeologic purposes.

The cavernous subdivision of the upper Glen Rose Limestone is approximately $115 \mathrm{ft}$ thick in northern Bexar County (Clark, 2005). During field surveys from 2008 through 2010, the uppermost $70 \mathrm{ft}$ of the cavernous member of the upper Glen Rose Limestone outcrop was identified in the study area. The upper Glen Rose limestone is composed of alternating and interfingering marl and dolomitic mudstone to packstone with local solution zones (table 1).

\section{Contact Between the Trinity and Edwards Groups}

In the study area, the contact between the Kainer Formation of the Edwards Group and the underlying Glen Rose Limestone of the Trinity Group is disconformable. A disconformable contact has a period of erosion between depositional cycles (Neuendorf and others, 2005). Mapping done from 2008 through 2010 for this report indicates that the contact between the Glen Rose Limestone formation of the Trinity Group and the Kainer Formation of the Edwards Group is topographically $50 \mathrm{ft}$ lower throughout the study area than shown in a previous, larger-scale report (Stein and Ozuna, 1996). The upper Glen Rose Limestone is easily recognizable from the overlying Kainer Formation because of its stairstep topography that develops between beds of marl and limestones.

\section{Stratigraphy of the Edwards Group}

The Edwards Group formed in shallow marine waters and is divided into two formations, the Kainer and Person (Rose, 1972). The Kainer and Person Formations were subdivided by Rose (1972) into seven informal members. The Kainer Formation is approximately $255 \mathrm{ft}$ thick in the study area; it is composed of the following members, in ascending order: the basal nodular, dolomitic, Kirschberg evaporite, and grainstone (table 1) (Rose, 1972; Ashworth, 1983; Clark and others, 2009). The mapped Edwards Group subdivisions in the study area include parts of all four members of the Kainer Formation. The overlying Person Formation was not observed; it has been eroded from the study area.

The Lower Cretaceous depositional environment of the Edwards Group rocks is defined as a complex, highly variable carbonate platform environment disrupted over time by erratic sea-level fluctuations that were contemporaneous with deposition (Barker and others, 1994; Clark and others, 2009). The depositional sequence stratigraphy model for the Edwards Group generally is characterized as a detached, rimmed carbonate platform with layer-cake lithologies and periodic karst development (Ashworth, 1983; Maclay, 1995). Clark and others (2009) reported that an episode of subaerial exposure and incipient karst development occurred in the middle part of the Kainer Formation.

The lowest member of the Kainer Formation, the basal nodular member, was measured as approximately $50 \mathrm{ft}$ thick in the study area and composed of interbedded shaley, nodular mudstones to grainstones. The grainstones are usually composed of the single celled miliolid foraminifera. Bedding is massive, commonly with a nodular, burrowed appearance. The basal nodular member commonly contains pyrite-replaced marker fossils known as black rotund bodies (BRBs). According to Maclay and Small (1984), BRBs are small (0.1-0.5 millimeters in diameter), spherical, dark colored textural features of unknown origin. Because they weather rapidly, BRBs are not present everywhere, but where present, they resemble small, black- to rust-colored spots (Maclay and Small, 1986; Ted Small, U.S. Geological Survey, oral commun., 2002). The nodular nature of this unit results from the compaction of heavily burrowed wackestones and mudstones (Shinn and others, 1977). Fossils, ranging from sparse to locally abundant and visible without magnification, include miliolids, gastropods, and Exogyra texana.

The basal nodular member grades into the dolomitic member. The gradational transition alternates between burrowed mudstones and miliolid grainstones. The dolomitic member was measured as approximately $110 \mathrm{ft}$ thick in 


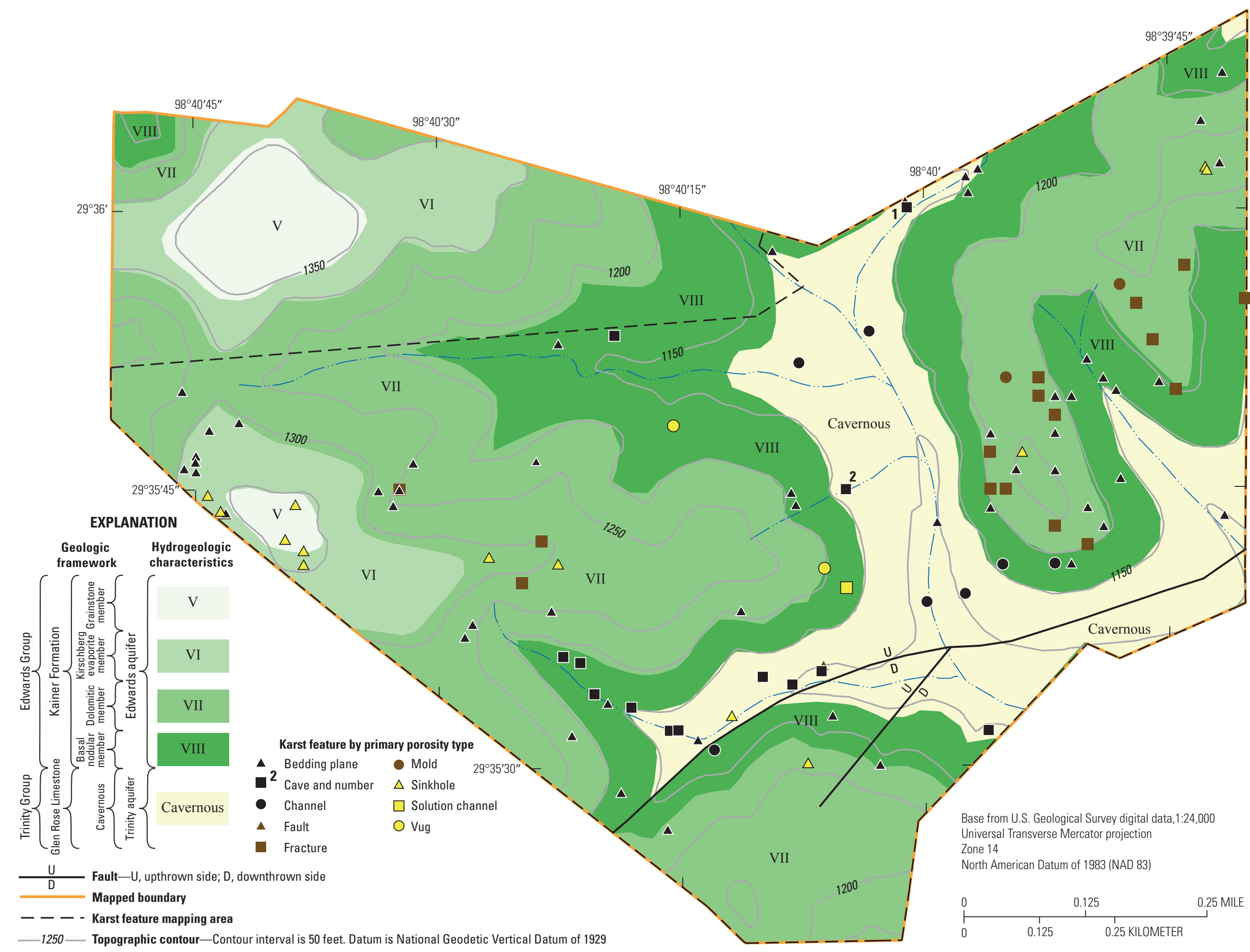

Figure 2. Geologic framework and hydrogeologic characteristics of the study area, along with locations of faults, caves, and karst features other than caves, in the southern part of the Rancho Diana Natural Area, northern Bexar County, Texas. 
Table 1. Summary of the geologic framework and hydrogeologic characteristics of the Edwards and upper Trinity aquifers outcropping in the southern part of the Rancho Diana Natural Area, northern Bexar County, Texas.

[Group, formation, members modified from Rose (1972), Ashworth (1983) and Clark and others (2009); hydrogeologic subdivisions (aquifers, zones) from Maclay and Small (1976), Ashworth (1983), Barker and Ardis (1996), Clark (2003, 2005) Clark and others (2009), Shah and others (2008); lithologic terminology modified from Dunham (1962); and porosity type modified from Choquette and Pray (1970), permeability and porosity type description from field observations]

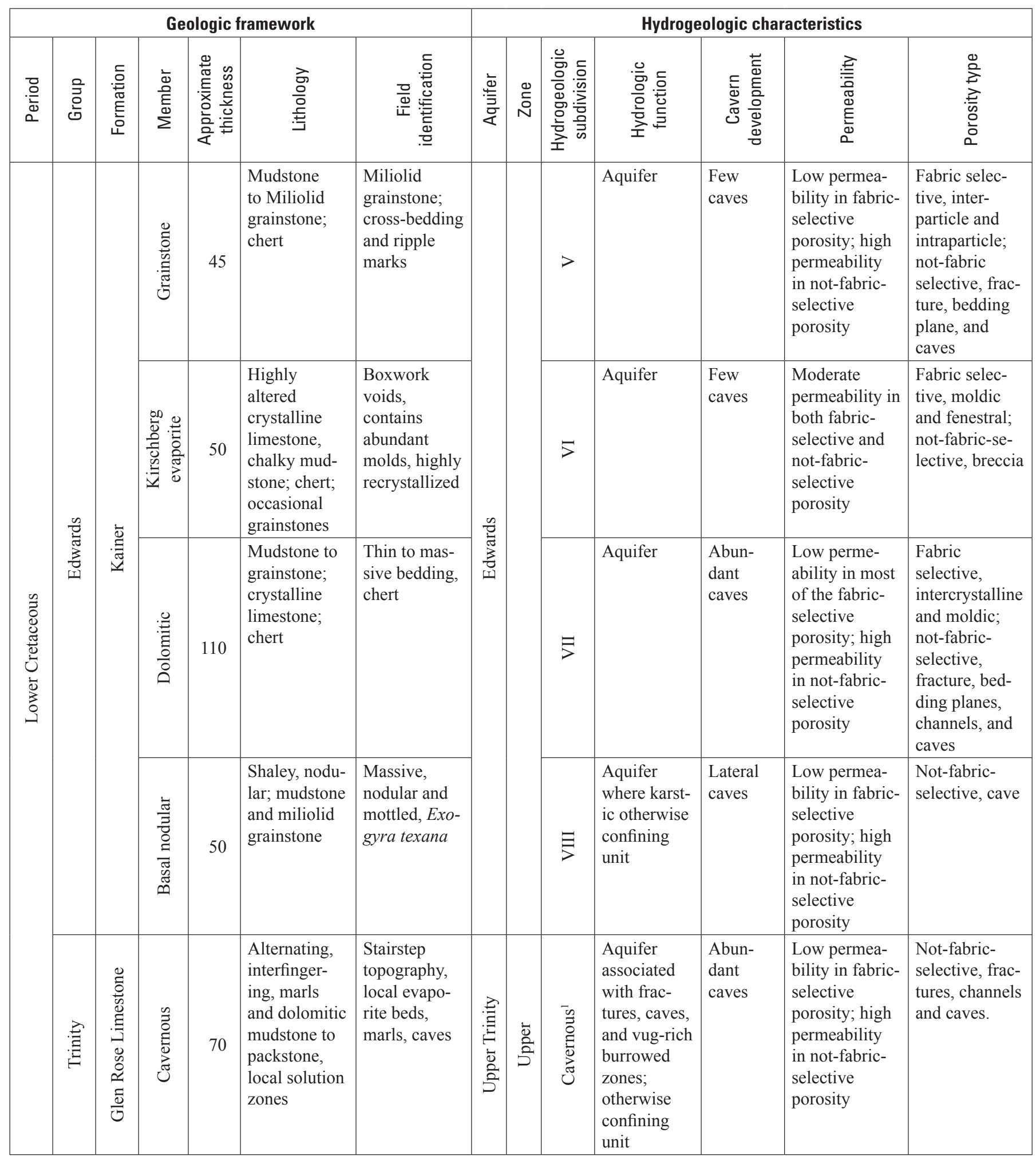

${ }^{1}$ Formerly referred to as Interval A (Clark and others, 2009) 
the study area and composed of mudstone to grainstones, crystalline limestone, and chert. Chert, a sedimentary rock composed of microcrystalline quartz (Neuendorf and others, 2005), first appears in the Edwards Group in the dolomitic member approximately $20 \mathrm{ft}$ above the contact between the basal nodular member and the dolomitic member and can be found throughout the remainder of the Edwards Group as nodules and beds (Ted Small, U.S. Geological Survey, oral commun., 2002). An example of a chert nodule found at the Rancho Diana Natural Area that was approximately 3.5 inches in diameter is shown in figure 3. The authors have observed during the course of this study (in addition to observations made at other sites in northern Bexar County) that a marker bed containing the fossils of the Turritella sp., Tylostoma sp., and Pecten sp. can be observed in proximity to the chert bed; markers of chert and fossil beds aid in mapping. Bedding within the dolomitic member varies from thin to thick beds. The authors also observed a massive bed containing large molds of rudist bivalves (caprinid rudists) (Scott, 2002) in the top of the dolomitic member; some of which have been replaced with chert.

The contact of the Kirschberg evaporite member with the underlying dolomitic member (grainstone) is conformable and gradational. The approximately 50 -ft thick Kirschberg evaporite member was not previously mapped in the study area. The Kirschberg evaporite member was deposited in an intertidal to supratidal marine environment (Rose, 1972). It is composed of highly altered crystalline limestone, chalky mudstone (with occasional grainstone facies), and chert (Stein and Ozuna, 1996). Occasionally marine fossil hash (fossil debris) can be found as thick lenses; the fossil debris likely were deposited in tidal channels or pools. The authors occasionally found evidence of what were probably stromatilites, the oldest known forms of life (Schopf and others, 2007). The stromatilites appear as rounded, layered structures with diagenetic variations between the layers resulting in some layers being more resistant than others to erosion.

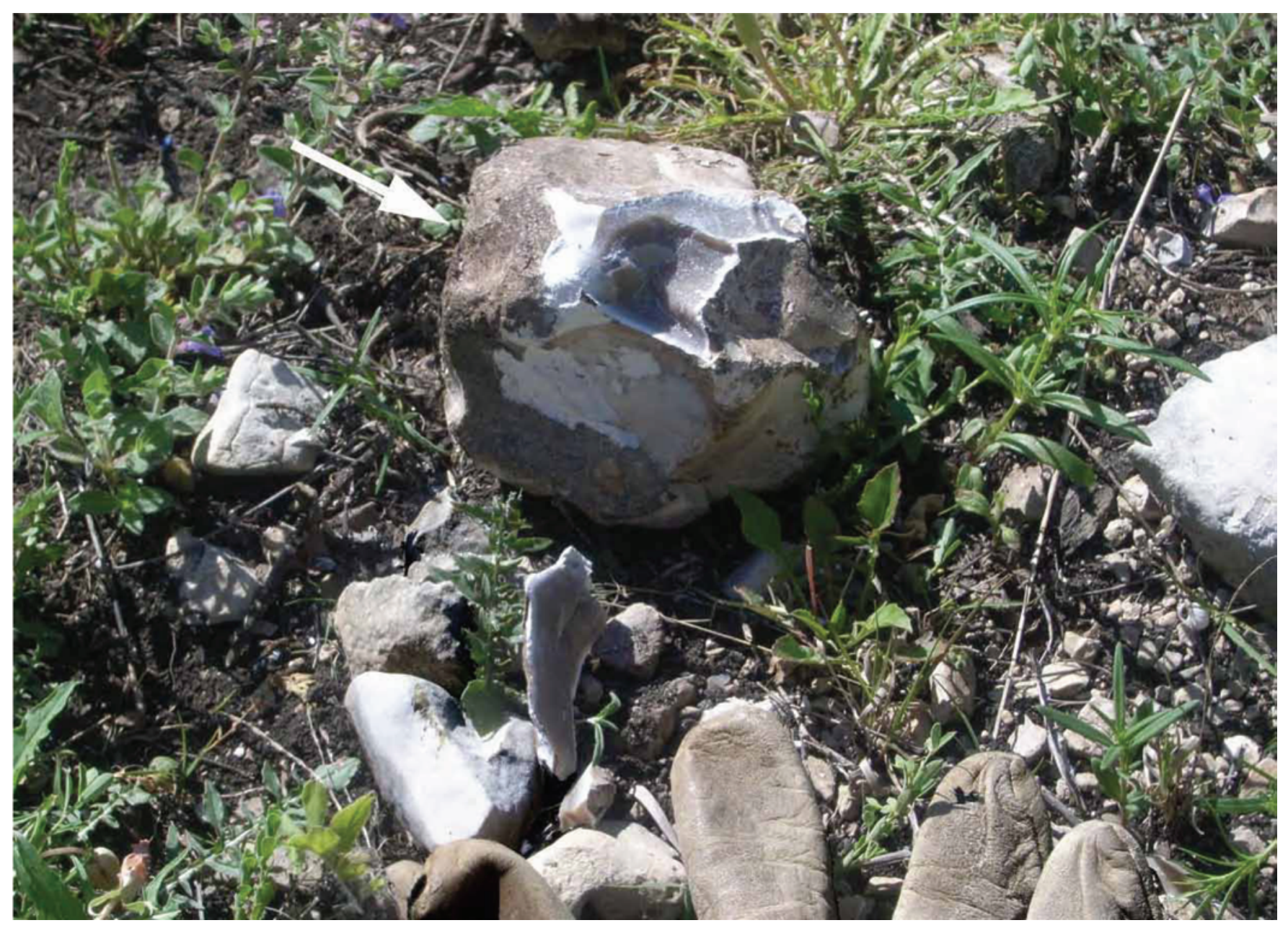

Figure 3. Typical chert nodule (white arrow) found in the southern part of the Rancho Diana Natural Area, northern Bexar County, Texas. 
The contact between the grainstone member and the underlying Kirschberg evaporite member is disconformable (Rose, 1972). Figure 4 provides an example of the contact between the Kirschberg evaporate member and the overlying grainstone member. The grainstone member of the Kainer Formation is the top formation and caps the highest hills in the western part of the study area (fig. 2). Although Stein and Ozuna (1996) reported the grainstone member was 50-60 ft thick in parts of northern Bexar County, they did not show it as part of the surface geology of study area. The grainstone member is composed of mudstone to miliolid grainstone and often contains sedimentary structures such as crossbeds and ripple-marked surfaces. The grainstone member was measured to be approximately $45 \mathrm{ft}$ thick in the study area.

\section{Structural Features}

The faults in northern Bexar County are part of the Balcones fault zone (Hill and Vaughn, 1898), the primary structural feature in the region (fig. 1). Most of the faults in the Balcones fault zone trend southwest to northeast, but a smaller set of cross-faults trend southeast to northwest (Clark, 2005). Many of the faults in Bexar County mark the trace of shatter zones, where the faults are not single, sharp breaks as shown by a single line placed on a map (Arnow, 1959). Secondary fractures, which resulted from the faulting, are generally at angles between 45 and 145 degrees from the main fault (Clark, 2005).

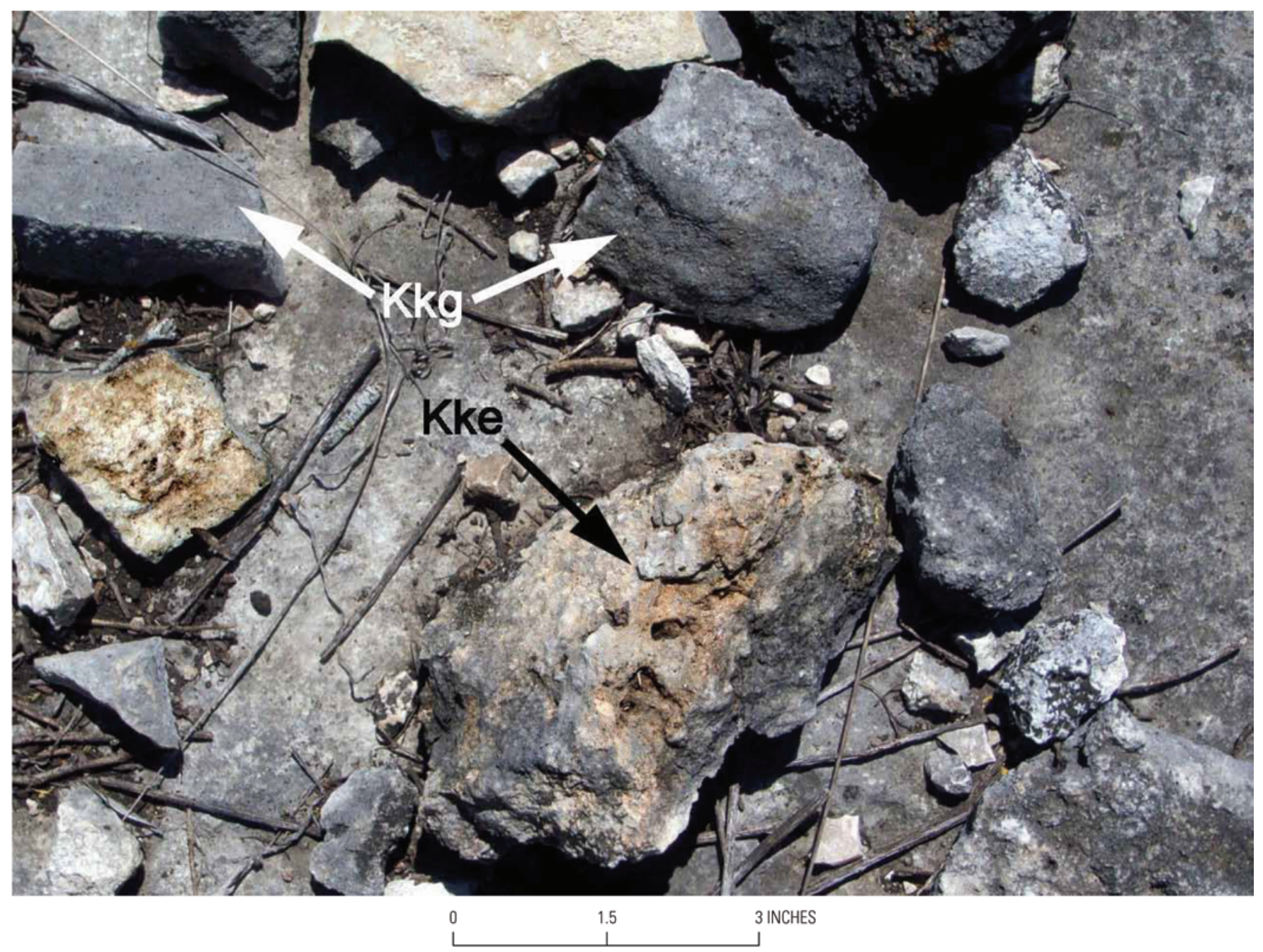

Figure 4. Contact between the Kirschberg evaporite member (Kke) (black arrow) in the foreground and grainstone member (Kkg) (white arrows) of the southern part of the Rancho Diana Natural Area, northern Bexar County, Texas. 
Stein and Ozuna (1996, plate 1) depicted two faults crossing the study area - a northern fault and a southern fault; however, no evidence for the existence of the northern fault was found during field mapping done for this report. The southern fault was mapped during the field work done for this study but at a slightly different strike angle (fig. 2). This fault has a vertical displacement of approximately $30 \mathrm{ft}$. A secondary splay fault was also mapped to the south of the main fault. Vertical displacement of the splay fault is approximately $5 \mathrm{ft}$.

Generally, the faults are en echelon and normal, with the fault blocks typically downthrown to the southeast toward the coast. Some of the faults might not result in topographic relief, partly because the rocks on both sides of the fault have similar weathering characteristics, and possibly because the rate of movement was approximately the same as the rate of erosion (Stein and Ozuna, 1996). The dip angles of faults in the upper Glen Rose Limestone range from 52 to 75 degrees. In contrast, dip angles are nearly vertical in the Kainer Formation (Clark, 2005).

A regional bedding dip of 10 to $15 \mathrm{ft}$ per mile to the south-southeast in Bexar County was reported by Arnow (1959). Based on field observations, it is known that bedding between the fault planes in most of the study area is nearly horizontal with a slight dip to the north of less than 1 degree.

\section{Hydrogeologic Characteristics}

Permeability and porosity are important controls of groundwater flow in the study area. Permeability is the capacity of a porous rock to transmit a fluid (Lohman and others, 1972). Permeability is dependent on the types of porosity as well as the effective porosity (Fetter, 1994) and can vary within the same rock type by location. For example, a formation that intrinsically contains relatively low permeability in most locations might have been fractured by faulting in some locations, followed by dissolution of the rock matrix allowing for localized areas of high permeability (Caine and others, 1996; White, 1988). Porosity in carbonate rocks is classified as either fabric selective or not-fabric selective (Choquette and Pray, 1970). Fabric-selective porosity is secondary porosity that preferentially developed along specific sedimentary structures, strata, or mineralogy. An example of fabric-selective porosity is moldic porosity that formed from the diagenesis of a shell. Not-fabric-selective porosity is secondary porosity that developed without the influence of sedimentary structures or is not associated with the original sedimentary or diagenetic process, or both. An example of not-fabric-selective porosity is a fault or cave. Porosity types observed in the study area that can increase the effective porosity (U.S. Geological Survey, 2011b) include solutionally enlarged caves, sinkholes, fractures, bedding planes, channels, molds, and vugs.

\section{Edwards Aquifer}

Stein and Ozuna (1996) noted the Edwards aquifer is one of the most permeable and productive aquifers in the world and is the most prolific groundwater source in Bexar County. Recharge to the Edwards aquifer is a result of diffuse infiltration on the recharge zone and focused recharge concentrated in streambeds that cross fractures and faults and often contain caves and sinkholes (Small and Hanson, 1994; Mahler and others, 2006). Maclay and Small (1984) categorized the seven informal lithostratigraphic members of Rose (1972) into seven informal hydrostratigraphic subdivisions on the basis of subsurface porosity. Maclay and Small (1984) also included the overlying Georgetown Formation as an eighth informal hydrostratigraphic subdivision to complete their characterization of the Edwards aquifer. The Edwards aquifer has relatively high permeability resulting, in part, from the development of secondary porosity (Maclay and Small, 1976). In outcrop areas, the porosity and permeability of the Edwards aquifer are the result of lithology, depositional history, secondary diagenesis, and karstification (Stein and Ozuna, 1996). Hydrogeologic subdivisions V, VI, VII, and VIII of the Edwards aquifer (Maclay and Small, 1976) were observed in the outcrop of the Edwards aquifer in the study area and mapped. Figure 2 also shows the location of karst features such as caves, sinkholes, fractures, bedding planes, channels, molds, and vugs (two caves shown in figure 2 were assigned a number because they are mentioned in the Hydrogeologic Characteristics section).

Porosity types observed in the study area that can increase the effective porosity and increase permeability include solutionally enlarged caves, sinkholes, fractures, bedding planes, channels, molds and vugs. The authors' field observations revealed hydrogeologic subdivision $\mathrm{V}$ has less effective permeability compared to subdivisions VI and VII (table 1). Subdivision V contains locally fabric-selective interparticle and intraparticle porosity as well as not-fabricselective fracture, bedding plane, and cavern porosity (Choquette and Pray, 1970). Subdivision V is porous and permeable along fractures, bedding planes, and caves.

Hydrogeologic subdivision VI has interconnected porosity with moderate permeability. Hydrogeologic subdivision VI primary porosity is fabric-selective moldic porosity associated with the dissolution of evaporite minerals. Moldic porosity often forms box-like structures (Oldershaw and Beales, 1969), which were termed "boxwork" in the Edwards aquifer by Maclay and Small (1976). Boxwork moldic porosity has large, often square molds in which the matrix rock forms the walls of the box (fig. 5). Figure 6 shows fabric-selective moldic porosity in the Edwards aquifer observed in the study area. Boxwork porosity was not found throughout subdivision VI but was interbedded and interfingered with more massive limestone beds. Hydrogeologic subdivision VI also contains 

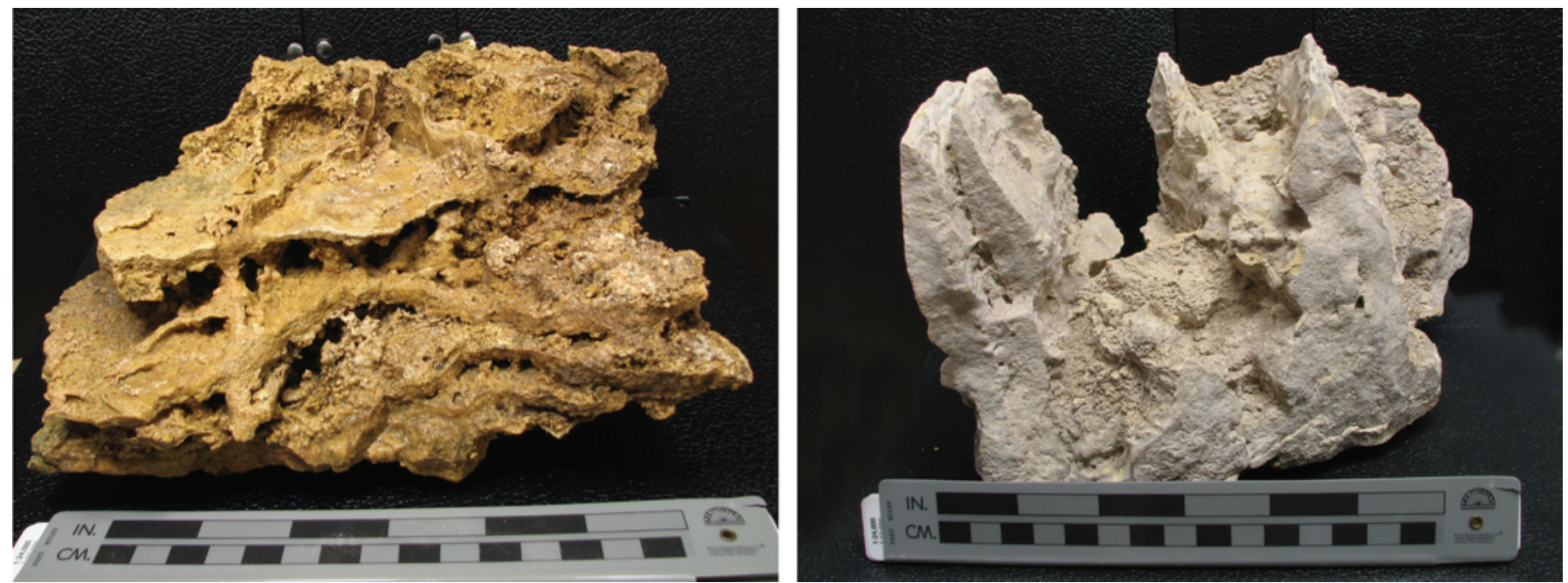

Figure 5. Boxwork moldic porosity from evaporite beds.

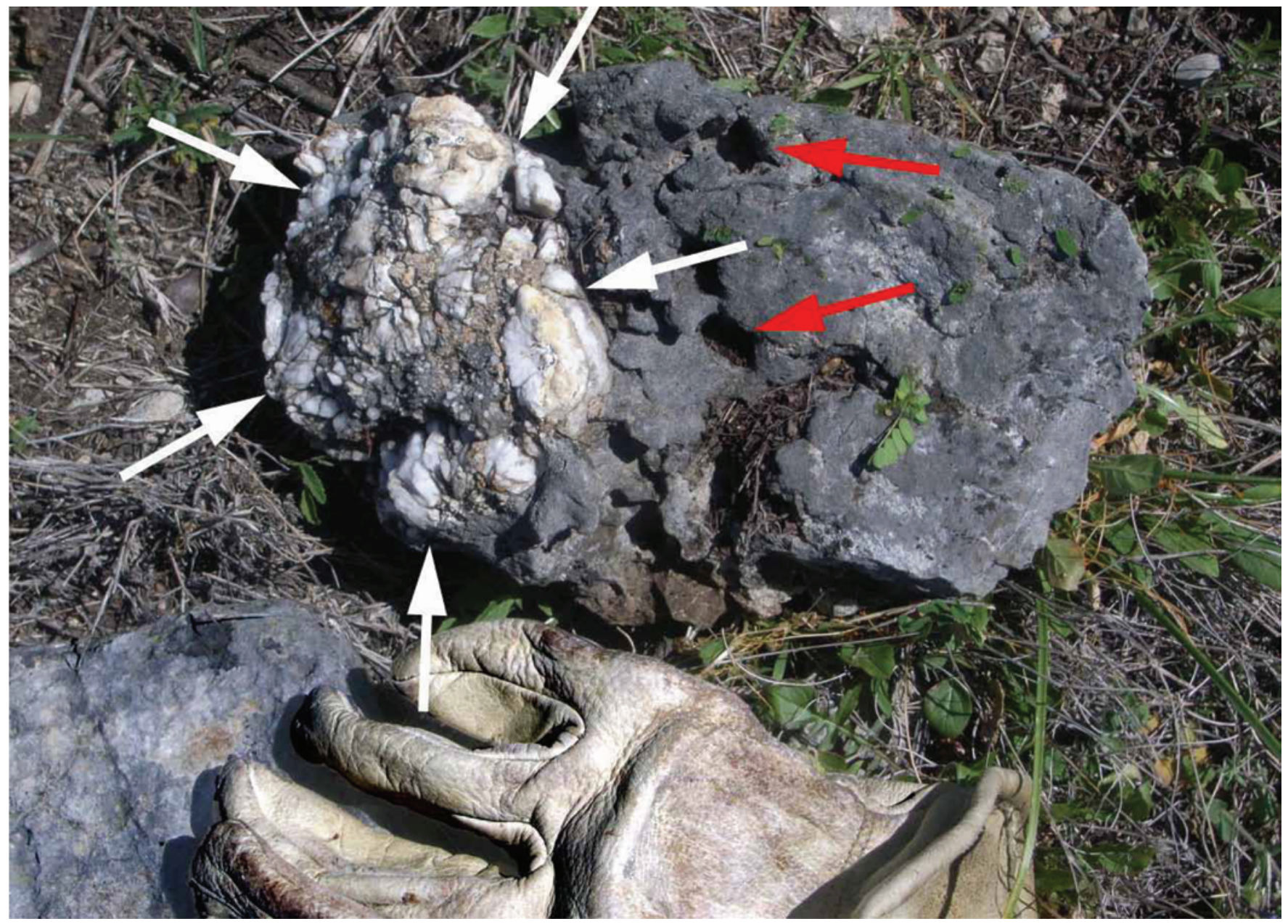

Figure 6. Fabric-selective moldic porosity (red arrows) in a limestone nodule containing chert (white arrows) observed in the southern part of the Rancho Diana Natural Area, northern Bexar County, Texas. 


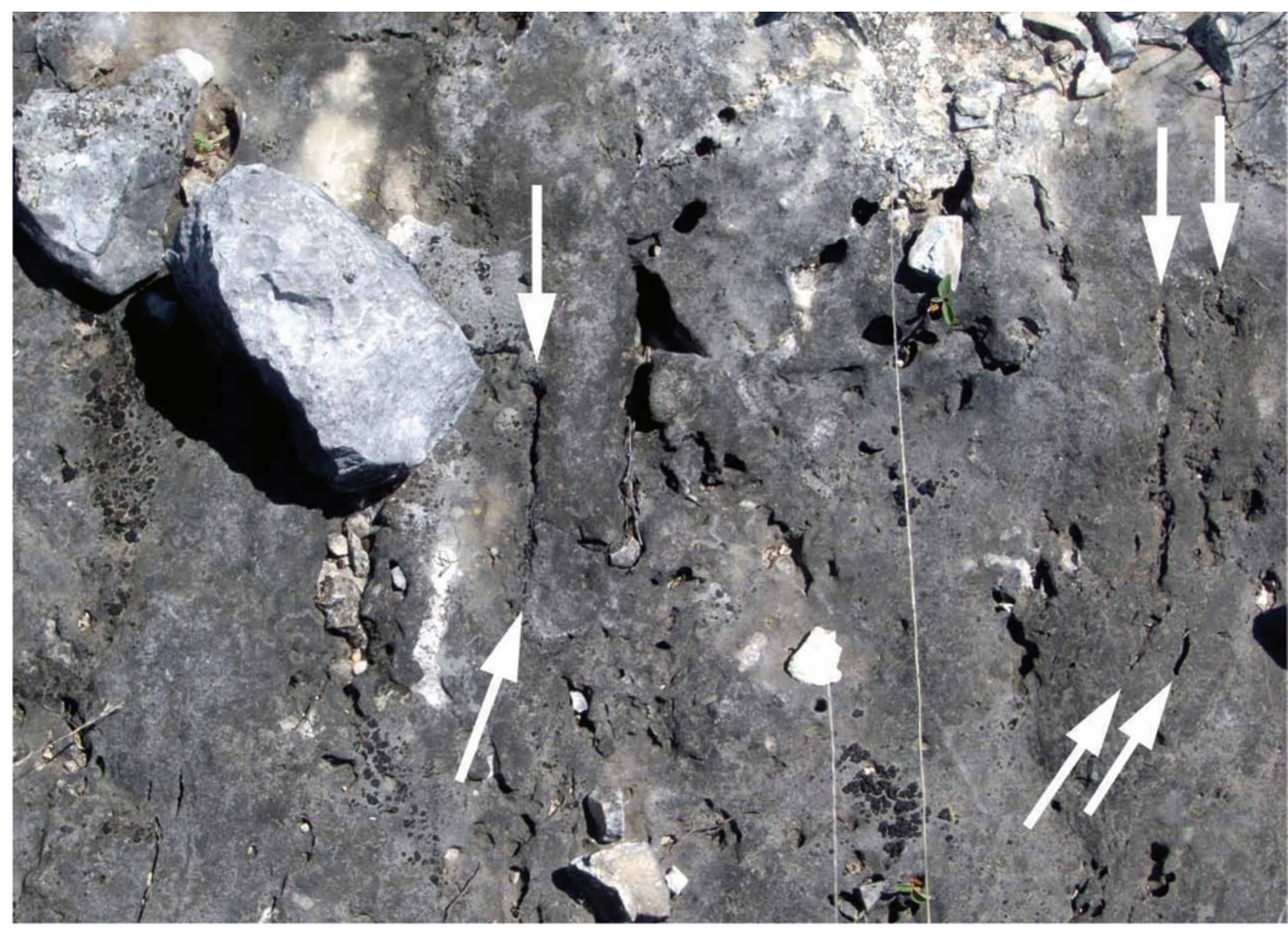

0

1.5

3 INCHES

Figure 7. Fabric-selective fenestral porosity (white arrows) in hydrogeologic subdivision $\mathrm{VI}$ of the Edwards aquifer observed in the southern part of the Rancho Diana Natural Area, northern Bexar County, Texas.

not-fabric-selective breccia porosity, which is associated with cavern collapse, faulting, or both (Bureau of Economic Geology, 2011). Fenestral (linear) porosity (fig. 7), another type of fabric-selective porosity (Choquette and Pray, 1970), also was observed. In some cases, the fenestral porosity appeared (fig. 7) to form in fossilized stromatolite fossils, probably from slight changes in the lithology.

Field observations revealed hydrologic subdivision VII contains both fabric-selective and not-fabric-selective porosity. The fabric-selective porosity is either intercrystalline or moldic (fig. 8). Some of the beds within this subdivision are burrowed and dissolved to the extent of being honeycombed and, therefore, permeable. Isolated molds with large fabricselective porosity are found in some beds, but because the openings are not connected, these beds contain relatively little permeability compared to the honeycombed beds. Not-fabricselective porosity consisted of solutionally enlarged caves, sinkholes, fractures, bedding planes, and channels. At the top of hydrogeologic subdivision VII is a massive limestone bed with interconnected moldic porosity (caprinid molds) and channel porosity. Examples of fabric-selective moldic porosity (caprinid molds) and channel porosity (white arrows) at the top of hydrogeologic subdivision VII (dolomitic member) are shown in figure 8 . The largest amounts of permeability in hydrogeologic subdivision VII are found in the channel porosity at the top of hydrogeologic subdivision VII and in the fractures and caves, which are found throughout the subdivision. Field mapping indicates recharge in the Edwards aquifer outcrop primarily occurs within the study area at the top of hydrogeologic subdivision VII.

In the absence of not-fabric-selective porosity, hydrogeologic subdivision VIII generally acts as a confining unit (Stein and Ozuna, 1996). Hydrogeologic subdivision VIII in the outcrop of the study area appears dominated by notfabric-selective porosity. The not-fabric-selective porosity is indicated by the presence of caves throughout the study area in this hydrogeologic subdivision. Five of the 13 caves identified were located in the outcrop of hydrogeologic subdivision VIII 


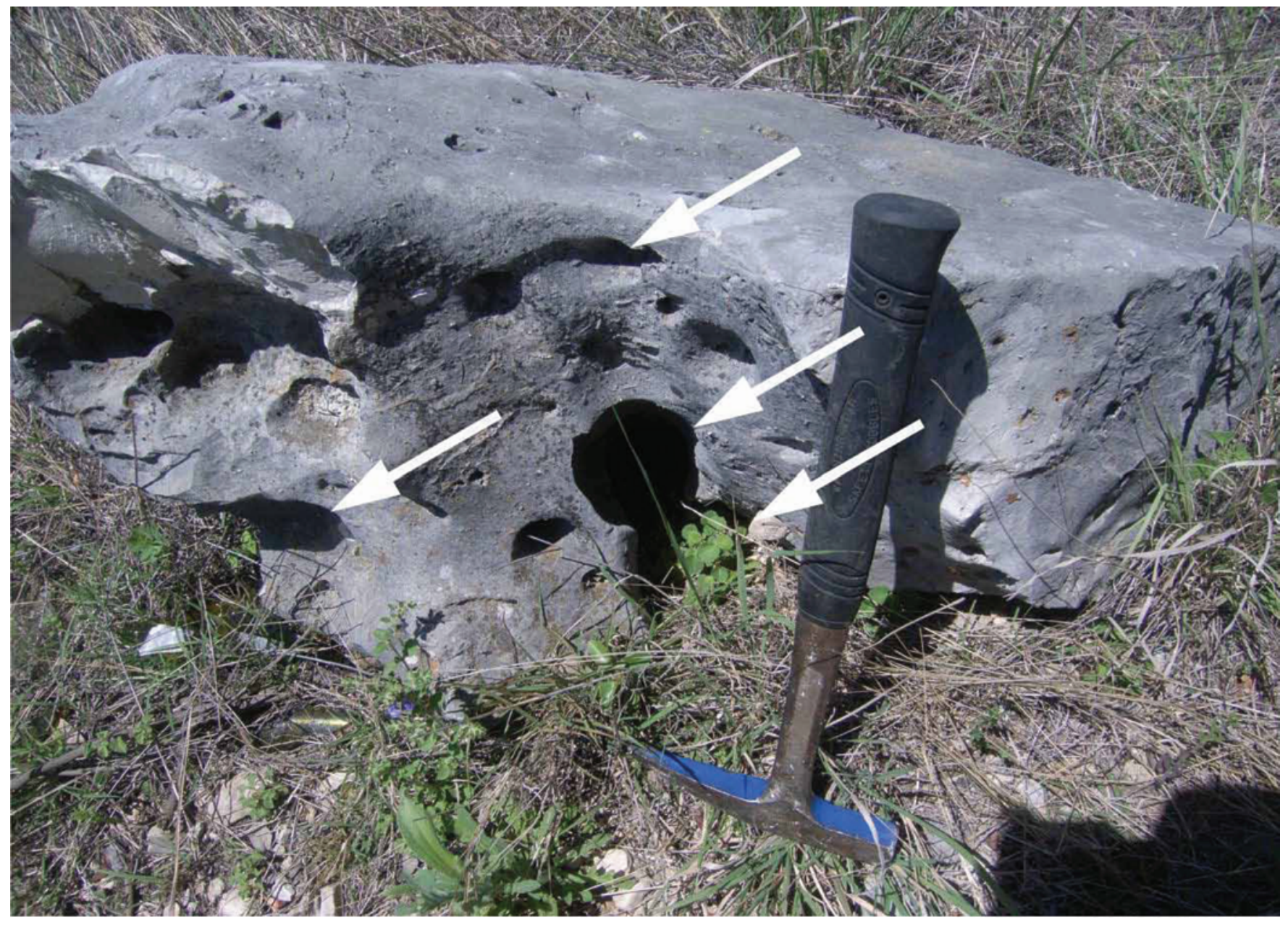

Figure 8 Fabric-selective moldic porosity (caprinid molds) and channel porosity (white arrows) at the top of hydrogeologic subdivision VII (dolomitic member) observed in the southern part of the Rancho Diana Natural Area, northern Bexar County, Texas.

of the Edwards aquifer (fig. 2). The caves tend to be linear with development along a bedding plane or coincident with a change in lithology. The lateral cave development might result from dissolution along bedding planes associated with lateral migration of infiltrating precipitation on the underlying, relatively impermeable upper Trinity aquifer. Because of the presence of numerous karst features in this hydrogeologic subdivision in the study area, it appears to function locally as an aquifer.

Based on field observations, water that enters the Edwards aquifer outcrop seemingly moves downward until it reaches the contact between hydrogeologic subdivision VIII (basal nodular) of the Edwards aquifer and the cavernous subdivision of the Trinity aquifer (upper Glen Rose Limestone). The decreased permeability of the upper Glen Rose Limestone causes the groundwater to flow laterally until it discharges at or near the outcrop of the contact of the Edwards and Upper Trinity aquifers. This flow pattern has been documented by other investigators (for example, Rose, 1972). Field mapping for this study also revealed that discharge along bedding planes occurs primarily as seeps near the contact between the Edwards aquifer and Upper Trinity aquifer outcrops. A schematic depiction of infiltration, discharge, and runoff processes as they are perceived by the authors for a typical small drainage in the study area with a cave developed in the cavernous subdivision of the Trinity aquifer outcrop is shown in figure 9; a debris pile immediately downstream from the cave is illustrated.

\section{Trinity Aquifer}

Barker and Ardis (1996) noted the Trinity aquifer is a vital water supply to much of northern Bexar County and other areas mostly north and northwest of San Antonio; they also reported (Barker and Ardis, 1996, p. 43) "the Trinity aquifer is recharged, in order of importance, by the (1) lateral subsurface inflow of groundwater from the Edwards Plateau, (2) infiltration of precipitation on the outcrop area, and (3) seepage of surface water from shallow, tributary streams in upland areas." 


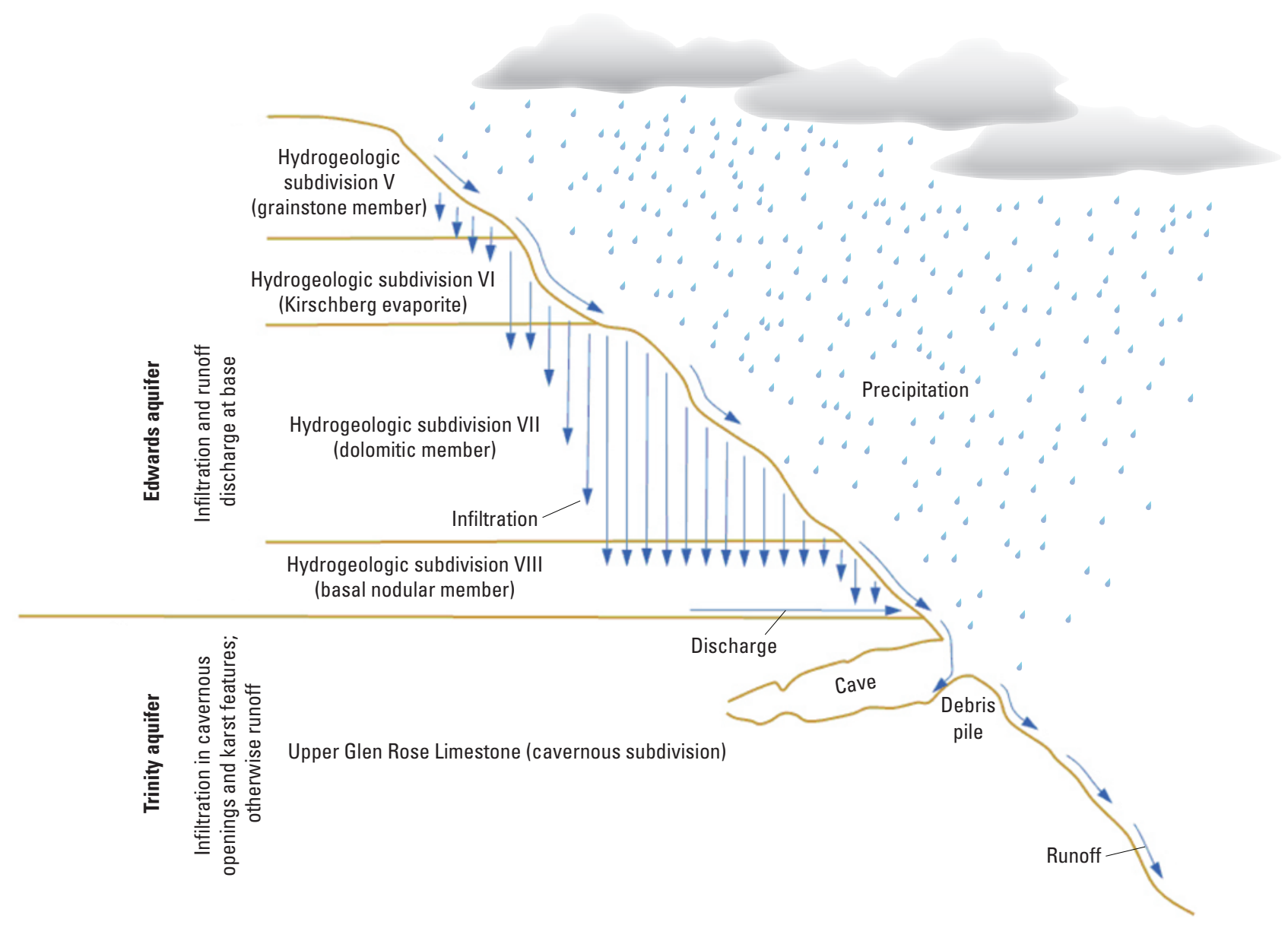

Figure 9. Simplified schematic representation of infiltration, discharge, and runoff processes in the southern part of the Rancho Diana Natural Area, northern Bexar County, Texas.

The upper member of the Glen Rose Limestone of the Trinity aquifer generally has a lower porosity and lower permeability compared to most formations of the Edwards aquifer (Barker and Ardis, 1996); however, Veni (1994) found that the Trinity aquifer is uncharacteristically permeable in the outcrop and shallow subcrop of northern Bexar County. Recent fieldmapping investigations by Clark $(2003,2005)$ and Clark and others (2009) support Veni's (1994) findings that parts of the upper Trinity aquifer are more porous and permeable than previously reported.

The cavernous hydrogeologic subdivision of the upper Trinity aquifer is approximately $70 \mathrm{ft}$ thick in the study area; this unit is named for its abundance of caves as compared to the remaining section of the upper Trinity aquifer (Clark and others, 2009). The only part of the Trinity aquifer exposed in outcrop in the study area is the cavernous subdivision. Of the 13 caves found in the study area, 8 were located in the outcrop of the cavernous hydrogeologic subdivision of the upper Trinity aquifer (fig. 2). Porosity in the upper Trinity aquifer is generally not-fabric-selective but is related to fracturing. Cave development in the cavernous subdivision is associated with solutionally enlarged fractures and channel porosity that have become more interconnected or permeable over time and thus can provide an avenue for substantial recharge into the aquifer (Clark and others, 2009). Figure 2 shows the locations of caves in the study area, including those found in the cavernous subdivision in the study area, and figures 10 and 11 show caves representative of those within the cavernous subdivision. The contact between the cavernous subdivision in the upper Trinity aquifer and the overlying subdivision VIII 


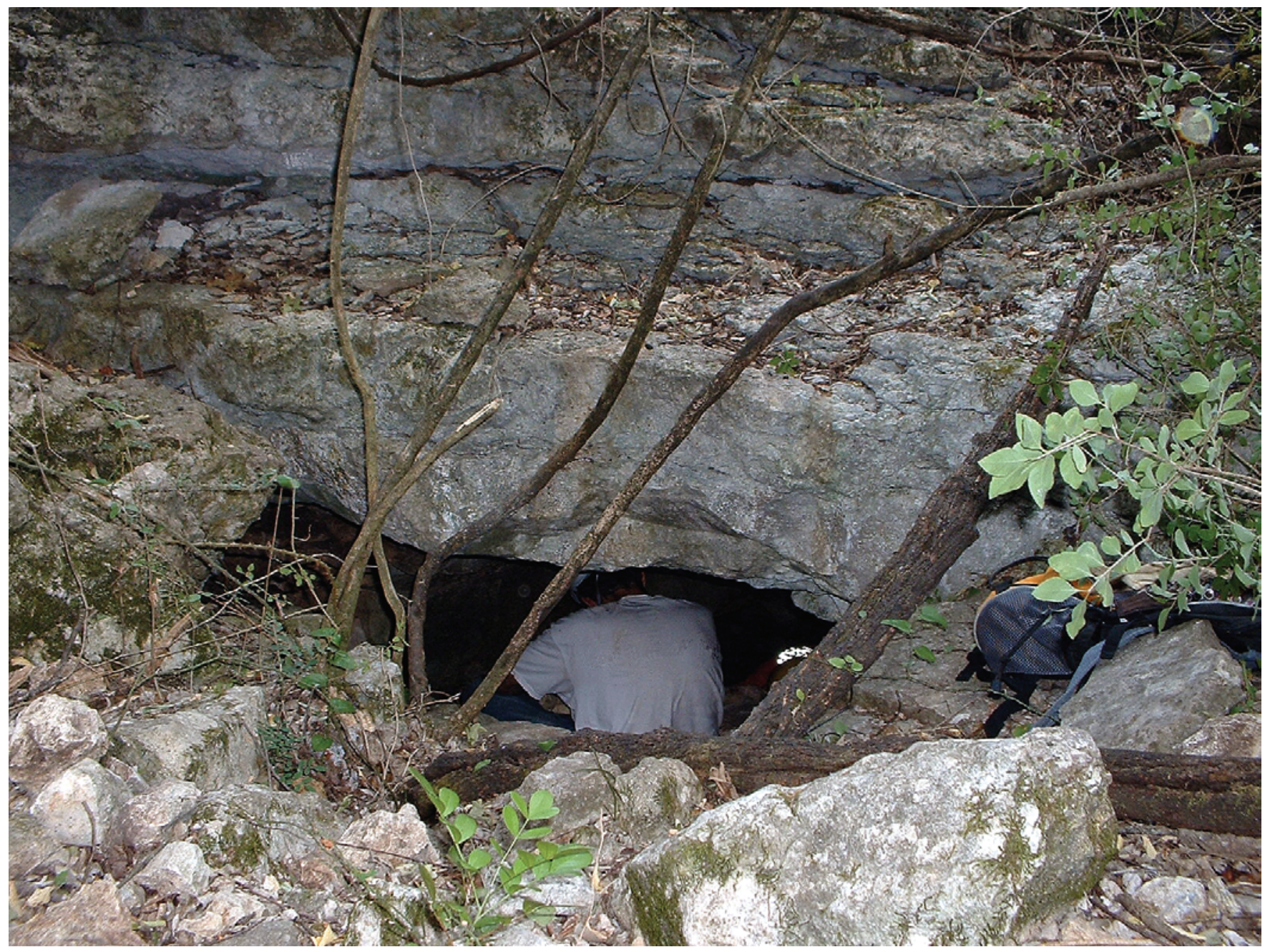

Figure 10. Cave (cave number 2; fig. 2) that developed in the hydrogeologic cavernous subdivision near the contact of the Edwards and upper Trinity aquifers in the southern part of the Rancho Diana Natural Area, northern Bexar County, Texas.

in the Edwards aquifer contains locally substantial cavern porosity with extremely large permeability (Clark and others, 2009) — properties that vary with depth below land surface (Lambert and others, 2010). Many of the springs in northern Bexar County are at the contact between the outcrop of the upper Trinity aquifer and the outcrop of the Edwards aquifer (Stein and Ozuna, 1996; Clark and others, 2009). Figure 10 shows an example of a cave that developed in the hydrogeologic cavernous subdivision a few feet below the contact of the Edwards and upper Trinity aquifers. This cave is in a small unmapped drainage and most, if not all, flow in this ephemeral stream enters the cave and some of the flow likely contributes to groundwater recharge (cave number 2; fig. 2). The capture of streamflow is accentuated by a debris pile immediately downstream from this cave opening.
Caves found during hydrogeologic mapping might have at one time been spring discharge points, but sufficient downcutting over geologic time in the rocks has occurred so that the spring discharge is now at lower elevations near the creek channel. The cave shown in figure 11 formed along the bedding plane in the cavernous subdivision of the upper Trinity aquifer. The shape and location of this cave show that it was probably a spring discharge point before downcutting lowered that point (Anthony, 2005). The mapped caves, sinkholes, and other areas of solutionally enlarged porosity might facilitate recharge during large storm events when runoff occurs on the hillsides (Ray, 2005); additional, areally distributed recharge in the study area occurs as a result of infiltration (Barker and Ardis, 1996). 


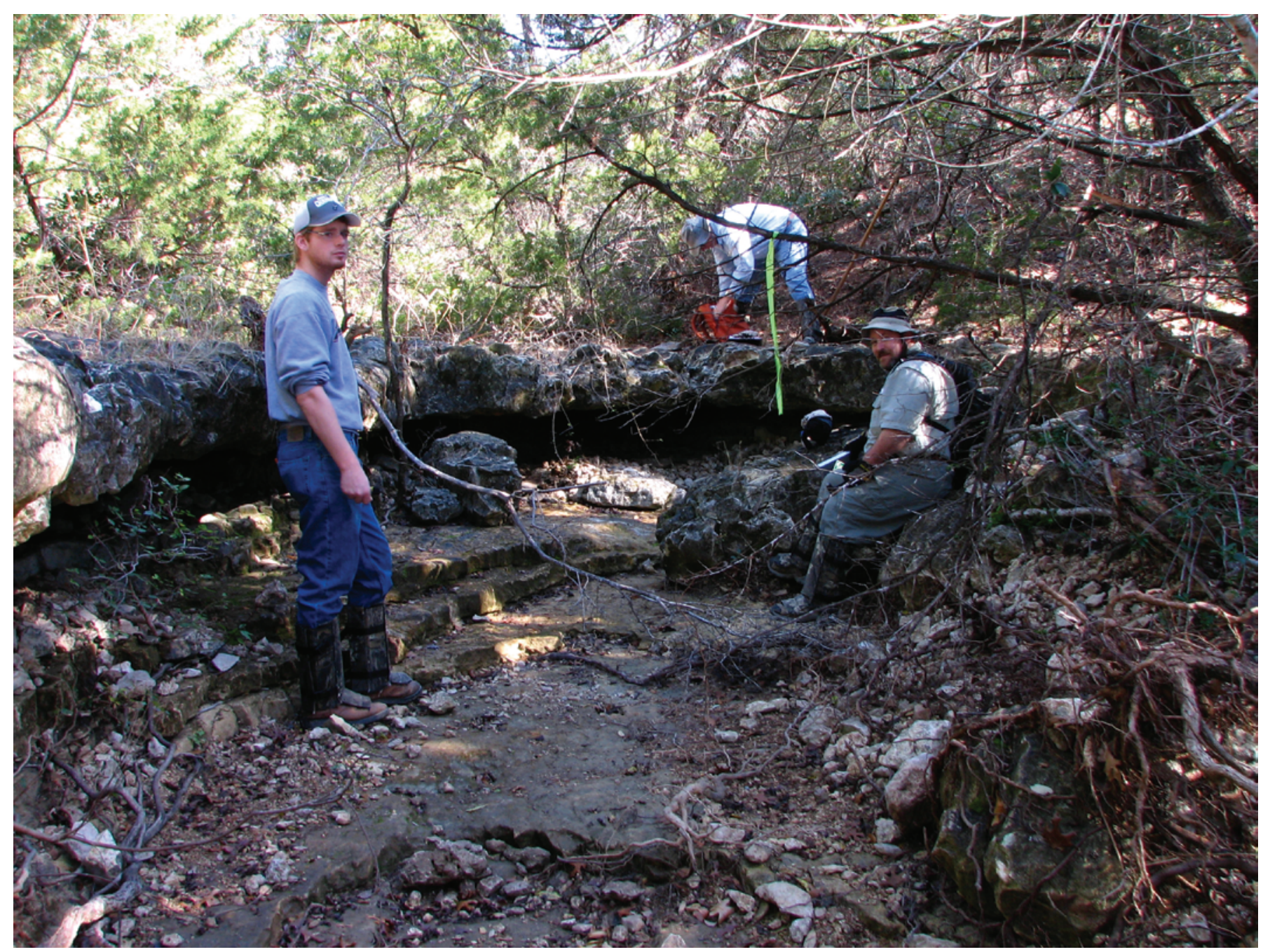

Figure 11. Cave (cave number 1; fig.2) that developed along a bedding plane in the cavernous subdivision of the upper Trinity aquifer in the southern part of the Rancho Diana Natural Area, northern Bexar County, Texas.

\section{Summary}

The area designated by the city of San Antonio as the Rancho Diana Natural Area overlies parts of the Edwards and Trinity aquifer recharge zones in northern Bexar County, near San Antonio, Texas. The U.S. Geological Survey, in cooperation with the city of San Antonio, documented the geologic framework and mapped the hydrogeologic characteristics for the southern part of the Rancho Diana Natural Area in northern Bexar County, Tex., during 2008-10. Detailed hydrogeologic characteristics of the Rancho Diana Natural Area are needed by water-resource managers to identify areas in which effects from urbanization might affect groundwater resources.

Geologic and hydrogeologic features were found by making field observations through the dense vegetation along gridlines spaced approximately $25 \mathrm{ft}$ apart and documenting the features as they were located. During the field investigation, surface geologic features were identified and karst features such as caves, sinkholes, and areas of solutionally enlarged porosity were located using hand-held Global Positioning System (GPS) units. The location data were used to create a map of the hydrogeologic subdivisions and the location of karst features.

All rocks exposed within the study area are of sedimentary origin and Lower Cretaceous in age. The valley floor is formed in the cavernous member of the upper Glen Rose Limestone of the Trinity Group. The hills are composed of the basal nodular member, dolomitic member, Kirschberg evaporite member, and grainstone member of the Kainer Formation of the Edwards Group. Field observations made during this study of the exposed formations and members indicate that the formations and members typically are composed of mudstones, wackestones, packstones, grainstones, and argillaceous limestones, along with marls. The overlying Person Formation of the Edwards Group has been removed by erosion from the study area. 
The upper Glen Rose Limestone is approximately 410 to $450 \mathrm{ft}$ thick, but only the upper $70 \mathrm{ft}$ is exposed in the study area. The Kainer Formation is approximately $255 \mathrm{ft}$ thick in the study area and is composed of, in ascending order, the basal nodular member, dolomitic member, Kirschberg evaporite member, and grainstone member. The basal nodular member is approximately $50 \mathrm{ft}$ thick in the study area and is composed of interbedded shaley, nodular limestones and mudstones to grainstones. The dolomitic member is approximately $110 \mathrm{ft}$ thick in the study area and composed of mudstone to grainstones, crystalline limestone, and chert. The approximately 50-ft-thick Kirschberg evaporite member was not previously mapped in the study area. The Kirschberg evaporite member is composed of highly altered crystalline limestone, chalky mudstone (with occasional grainstone), and chert. The grainstone member of the Kainer Formation is approximately $50-60 \mathrm{ft}$ thick in Bexar County, although only $45 \mathrm{ft}$ remain within the study area. Although the grainstone member caps some hill tops in the study area, previously it was not shown as present in the study area. The grainstone member is composed of mudstone to miliolid grainstone and often contains sedimentary structures such as crossbeds and ripple-marked surfaces.

The Balcones fault zone is the primary structural feature in the study area. Generally, the faults are en echelon and normal, with the fault blocks typically downthrown toward the southeast. Secondary fractures generally range between 45 and 145 degrees at an angle in plain view from the main fault. The angles of dip in the faults vary from 52 to 75 degrees in the shaley upper Glen Rose Limestone to nearly vertical in the dolomitic member of the Kainer Formation. Only one primary fault was mapped in the study area with a displacement of approximately $30 \mathrm{ft}$.

The Edwards and Trinity aquifers contain a combination of fabric-selective and not-fabric-selective porosities. Porosity types observed in the study area that can increase the effective porosity and increase permeability include solutionally enlarged caves, sinkholes, fractures, bedding planes, channels, molds, and vugs. The aquifers have been subdivided into hydrogeologic subdivisions. The Edwards aquifer outcrop in the study area includes hydrogeologic subdivisions V, VI, VII, and VIII. The only part of the Trinity aquifer exposed in outcrop in the study area is the cavernous subdivision.

Field observations indicate subdivision $\mathrm{V}$ contains locally fabric-selective interparticle and intraparticle porosity, as well as not-fabric-selective fracture, bedding plane, and cavern porosity. Subdivision $\mathrm{V}$ is porous and permeable along fractures, bedding planes, and caverns. Hydrogeologic subdivision VI has interconnected fabric-selective moldic porosity with moderate permeability. Hydrogeologic subdivision VI also contains not-fabric-selective breccia porosity which is associated with cavern collapse or faulting, or both. It also contains fenestral (linear) porosity, another type of fabric-selective porosity. Hydrogeologic subdivision VII contains both fabricselective and not-fabric-selective porosity. The fabric-selective porosity is either intercrystalline or moldic. Not-fabricselective porosity consisted of solutionally enlarged caves, sinkholes, fractures, bedding planes, and channels. At the top of hydrogeologic subdivision VII is a massive limestone bed with interconnected moldic porosity (caprinid molds) and channel porosity. The largest amounts of permeability in hydrogeologic subdivision VII are found in the channel porosity at the top of hydrogeologic subdivision VII and in the fractures and caves, which are found throughout the subdivision. Field observations revealed hydrogeologic subdivision VIII in the outcrop of the study area appears to be dominated by not-fabric-selective cavernous porosity. Hydrogeologic subdivision VIII in many locations is regarded as part of the lower confining unit because it contains negligible porosity and permeability.

The cavernous subdivision of the Trinity aquifer, so named because of its relatively abundant caves as compared to the remaining section of the upper Trinity aquifer, was found to be approximately $70 \mathrm{ft}$ thick in the study area. Porosity in the upper Trinity aquifer is generally not-fabric selective, but is related to fracturing. Cave development in the cavernous subdivision is associated with solutionally enlarged fracture and channel porosity that have become more interconnected or permeable over time and thus can provide an avenue for substantial recharge into the aquifer.

Caves found during hydrogeologic mapping might have been spring discharge points, but sufficient downcutting over geologic time in the rocks has occurred so that springs discharge at lower elevations near the creek channel. The mapped caves, sinkholes, and other areas of solutionally enlarged porosity might facilitate recharge during large storm events when runoff occurs on the hillsides; additional areally distributed recharge in the study area occurs as a result of infiltration.

\section{References Cited}

Anthony, D.M., 2005, Multilevel caves and landscape evolution, in Culver, D.C., and White, W.B., eds., Encyclopedia of Caves: Amsterdam, the Netherlands, Elsevier Science, p. 397-400.

Arnow, Ted, 1959, Ground-water geology of Bexar County, Texas: Texas Board of Water Engineers Bulletin 5911, 62 p.

Ashworth, J.B., 1983, Ground-water availability of the Lower Cretaceous formations of the Hill Country of south-central Texas: Texas Department of Water Resources, Report 273, 172 p., accessed March 22, 2011, at http://www.twdb.state. tx.us/publications/reports/groundwaterreports/gwreports/ R273/Rpt273.pdf.

Ashworth, J.B., and Hopkins, J., 1995, Major and minor aquifers of Texas: Texas Water Development Board Report 345, $69 \mathrm{p}$. 
Barker, R.A., and Ardis, A.F., 1996, Hydrogeologic framework of the Edwards-Trinity aquifer system, west-central Texas: U.S. Geological Survey Professional Paper 1421-B, 61 p.

Barker, R.A., Bush, P.W., and Baker, E.T.J., 1994, Geologic history and hydrogeologic setting of the Edwards-Trinity aquifer system, west-central Texas: U.S. Geological Survey Water-Resources Investigations Report 94-4039, 51 p.

Bureau of Economic Geology, 2011, Interactive online learning - Estimating permeability in carbonates using the rockfabric method: accessed April 18, 2011, at http://www.beg. utexas.edu/lmod/_IOL-CM07/old-4.29.03/cm07-step04.htm.

Caine, J.S., Evans, J.P., and Forster, C.B., 1996, Fault zone architecture and permeability structure: Geology, v. 24, no. 11, p. 1025-1028.

Choquette, P.W., and Pray, L.C., 1970, Geologic nomenclature and classification of porosity in sedimentary carbonates: American Association of Petroleum Geologists Bulletin, v. 54, no. 2, p. 207-250, accessed April 6, 2011, at http:// search.datapages.com/data/bulletns/1968-70/images/ pg/00540002/0200/02070.pdf.

city of San Antonio, 2010a, Edwards aquifer protection background: accessed August 19, 2010, at http://www. sanantonio.gov/edwards/background.asp.

city of San Antonio, 2010b, Parks and Recreation Department-Park inventory: accessed August 20, 2010, at http:// www.sanantonio.gov/sapar/pdf/parkinventory062510.pdf.

Clark, A.K., 2000, Vulnerability of ground water to contamination, Edwards aquifer recharge zone, Bexar County, Texas, 1998: U.S. Geological Survey Water-Resources Investigations Report 00-4149, 9 p., 1 plate.

Clark, A.K., 2003, Geologic framework and hydrogeologic features of the Glen Rose Limestone, Camp Bullis Training Site, Bexar County, Texas: U.S. Geological Survey WaterResources Investigations Report 03-4081, 9 p., 1 plate.

Clark, A.K., 2005, Geologic framework and hydrogeologic characteristics of the Glen Rose Limestone, Camp Stanley Storage Activity, Bexar County, Texas: U.S. Geological Survey Scientific Investigations Map 2831, 1 sheet.

Clark, A.R., Blome, C.D., and Faith, J.R, 2009, Map showing the geology and hydrostratigraphy of the Edwards aquifer catchment area, northern Bexar County, south-central Texas: U.S. Geological Survey Open-File Report 2009-1008, 24 p., 1 plate.

Dunham, R.J., 1962, Classification of carbonate rocks according to depositional texture, in Classification of carbonate rocks Symposium: American Association of Petroleum Geologist Memoir 1, p. 108-121, accessed April 6, 2011, at http://search.datapages.com/data/specpubs/carbona2/ images/a038/a0380001/0100/01080.pdf.
Fetter, C.W., 1994, Applied hydrogeology (3rd ed.): University of Wisconsin, Oshkosh, Prentice Hall, p. 691.

Field, M.S., 2006, Tracer-test design for losing stream-aquifer systems: International Journal of Speleology, v. 35, no. 1, p. 25-36.

Fisher, W.L., and Rodda, P.U., 1969, Edwards Formation (Lower Cretaceous), Texas dolomitization in a carbonate platform system: American Association of Petroleum Geologists Bulletin, v. 53, no. 1, p. 55-72.

Freeman, V.L., 1964, Geologic map of the Indian Wells quadrangle, Terrell and Brewster Counties, Texas: U.S. Geological Survey Miscellaneous Investigations Series Map, I-395, 1 sheet, scale 1:62,500.

Handbook of Texas Online, 2010, Bexar County: accessed August 20, 2010, at http://www.tshaonline.org/handbook/ online/articles/BB/hcb7.html.

Hanson, J.A., and Small, T.A., 1995, Geologic framework and hydrogeologic characteristics of the Edwards aquifer outcrop, Hays County, Texas: U.S. Geological Survey WaterResources Investigations Report 95-4265, 10 p.

Hill, R.T., 1891, The Comanche series of the Texas-Arkansas region: Geological Society of America Bulletin, v. 2, p. 503-528.

Hill, R.T., and Vaughn, T.W., 1898, Geology of the Edwards Plateau and Rio Grande Plain adjacent to Austin and San Antonio, Texas, with reference to the occurrence of underground waters: U.S. Geological Survey 18th Annual Report, pt. 2, p. 193-321.

Lambert, R.B., Hunt, A.G., Stanton, G.P., and Nyman, M.B., 2010, Lithologic and physicochemical properties and hydraulics of flow in and near the freshwater/saline-water transition zone, San Antonio segment of the Edwards aquifer, south-central Texas, based on water-level and borehole geophysical log data, 1999-2007: U.S. Geological Survey Scientific Investigations Report 2010-5122, 69 p. (appendixes available online at http://pubs.usgs.gov/ sir/2010/5122/).

Lohman, S.W., and others, 1972, Definitions of selected ground-water terms - revisions and conceptual refinements: U.S. Geological Survey Water-Supply Paper 1988, 21 p.

Lozo, F.E., and Smith, C.I., 1964, Revision of Comanche Cretaceous stratigraphic nomenclature, southern Edwards Plateau, southwest Texas: Gulf Coast Association of Geological Societies Transactions, v. 14, p. 285-306.

Maclay, R.W., 1995, Geology and hydrology of the Edwards Aquifer in the San Antonio Area, Texas: U.S. Geological Survey Water-Resources Investigations Report 95-4186, $54 \mathrm{p}$. 
Maclay, R.W., and Small, T.A., 1976, Progress report on geology of the Edwards aquifer, San Antonio area, Texas, and preliminary interpretation of borehole geophysical and laboratory data on carbonate rocks: U.S. Geological Survey Open-File Report 76-627, 65 p.

Maclay, R.W., and Small, T.A., 1984, Carbonate geology and hydrology of the Edwards aquifer in the San Antonio area, Texas: U.S. Geological Survey Open-File Report 83-537, $72 \mathrm{p}$.

Maclay, R.W., and Small, T.A., 1986, Carbonate geology and hydrology of the Edwards aquifer in the San Antonio area, Texas: Texas Water Development Board Report 296, 63 p.

Mahler, B.J., Garner, B.D., Musgrove, M., Guilfoyle, A.L., and Rao, M.V., 2006, Recent (2003-05) water quality of Barton Springs, Austin, Texas, with emphasis on factors affecting variability: U.S. Geological Survey Scientific Investigations Report 2006-5299, 83 p., 5 appendixes.

National Weather Service, 2010, San Antonio climate summary: accessed on August 26, 2010, at http://www.srh.noaa. gov/images/ewx/sat/satclisum.pdf.

Neuendorf, K.K.E., Mehl, J.P., Jr., and Jackson, J.A., eds., 2005, Glossary of geology, (5th ed.): Alexandria, Va., American Geological Institute, 779 p.

Oldershaw, A.E., and Beales, F.W., 1969, Evaporite-solution brecciation and Devonian carbonate reservoir porosity in western Canada: American Association of Petroleum Geologist Bulletin, v. 53, no. 3, p. 503-512, accessed April 6, 2011, at http://doi.aapg.org/data/bulletns/1968-70/images/ pg/00530003/0500/05030.pdf.

Phillips, J.D., Martin, L.L., Nordberg, V.G., and Andrews, W.A., 2004, Divergent evolution in fluviokarst landscapes of central Kentucky: Earth Surface Processes Landforms, v. 29 , p. $700-819$.

Ray, J.A., 2005, Sinking streams and losing streams, in Culver, D.C., and White, W.B., eds., Encyclopedia of Caves: Elsevier Academic Press, Oxford, p. 509-514.

Rose, P.R., 1972, Edwards group, surface and subsurface, central Texas: Austin, University of Texas, Bureau of Economic Geology Report of Investigations 74, 198 p.

Ryan, Martin, and Meiman, Joe, 1996, An examination of short-term variations in water quality at a karst spring in Kentucky: Ground Water, v. 34, p. 23-30.

Saleh, A., Wu, H., Brown, C.S., Teagarden, F.M., McWilliams, S.M., Hauck, L.M., and Millican, J.S., 2009, Effect of brush control on evapotranspiration in the North Concho River watershed using the eddy covariance technique: Journal of Soil and Water Conservation, v. 64, no. 5, p. 336-349.
Schopf, J.W., Kudryatsev, A., Czaja, A.D., and Tripathi, A.B., 2007, Evidence of archean life - Stromatolites and microfossils: Precambrian Research, v. 158, p. 141-155.

Scott, Robert W., 2002, Albian caprinid rudists from Texas reevaluated: Journal of Paleontology, May 2002, v. 76, no. 3, p. $408-423$.

Sellards, E.H., Adkins, W.S., and Plummer, F.B., 1933, The geology of Texas-Stratigraphy: University of Texas at Austin, Bureau of Economic Geology Bulletin 3232, v. 1, $1,007 \mathrm{p}$.

Shah, S.D., Smith, B.D., Clark, A.K., Kress, W.H., 2008, A multi-tool geophysical and hydrogeological investigation of a karst aquifer system, Cibolo Canyon Development, Bexar County, Texas, in Kuniansky, E.L., ed., U.S. Geological Survey Karst Interest Group proceedings, Bowling Green, Kentucky, May 27-29, 2008: U.S. Geological Survey Scientific Investigations Report 2008-5023, p. 107-116.

Shinn, E.A., Halley, R.B., Hudson, J.H., and Lidz, B.H., 1977, Limestone compaction-An enigma: Geology, v. 5, p. 21-24.

Small, T.A., 1985, Identification and tabulation of geological contacts in the Edwards aquifer, San Antonio area, Texas: Texas Department of Water Resources LP-199, 54 p.

Small, T.A., and Hanson, J.A., 1994, Geologic framework and hydrogeologic characteristics of the Edwards aquifer outcrop, Comal County, Texas: U.S. Geological Survey Water-Resources Investigations Report 94-4117, 10 p.

Stein, W.G., and Ozuna, G.B., 1996, Geologic framework and hydrogeologic characteristics of the Edwards aquifer recharge zone, Bexar County, Texas: U.S. Geological Survey Water-Resources Investigations Report 95-4030, 8 p.

U.S. Geological Survey, 2011a, USGS groundwater information-What is karst: accessed April 11, 2011, at http://water. usgs.gov/ogw/karst/pages/whatiskarst.

U.S. Geological Survey, 2011b, Oregon Water Science Center-Glossary of hydrologic terms: accessed April 13, 2011, at http://or.water.usgs.gov/projs_dir/willgw/glossary. html\#E.

Veni, George, 1994, Geologic controls on cave development and the distribution of endemic cave fauna in the San Antonio, Texas, Region: Section 6 report prepared for Texas Parks and Wildlife Department and U.S. Fish and Wildlife Service, $99 \mathrm{p}$.

White, W.B., 1988, Geomorphology and hydrology of karst terrains: New York, Oxford University Press, 464 p.

Whitney, M.I., 1952, Some zone marker fossils of the Glen Rose Formation of Central Texas: Journal of Paleontology, v. 26 , no. 1, p. $65-73$. 
Publishing support provided by the:

Lafayette and Rolla Publishing Service Centers

For more information concerning this publication, contact:

Director, Texas Water Science Center

U.S. Geological Survey

1505 Ferguson Lane

Austin, Texas 78754-4733

(512) 927-3500

Or visit the Texas Water Science Center Web site at: http://tx.water.usgs.gov/ 



\section{通}

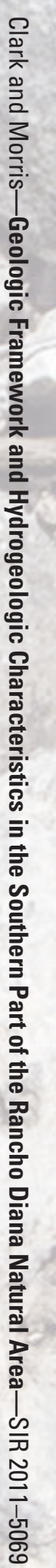

